\title{
Fracture-fill calcite as a record of microbial methanogenesis and fluid migration: a case study from the Devonian Antrim Shale, Michigan Basin
}

\author{
J. M. BUDAI ${ }^{1}$, A. M. MARTINI ${ }^{2}$, L. M. WALTER ${ }^{3}$ AND T. C. W. KU ${ }^{3}$ \\ ${ }^{1}$ Great Lakes Colleges Association, Ann Arbor, MI, USA; ${ }^{2}$ Department of Geology, Amberst College, Amberst, MA, USA; \\ ${ }^{3}$ Department of Geological Sciences, University of Michigan, Ann Arbor, MI, USA
}

\begin{abstract}
The Devonian Antrim Shale is an organic-rich, naturally fractured black shale in the Michigan Basin that serves as both a source and reservoir for natural gas. A well-developed network of major, through-going vertical fractures controls reservoir-scale permeability in the Antrim Shale. Many fractures are open, but some are partially sealed by calcite cements that retain isotopic evidence of widespread microbial methanogenesis. Fracture filling calcite displays an unusually broad spectrum of $\delta^{13} \mathrm{C}$ values ( +34 to $-41 \%$ PDB), suggesting that both aerobic and anaerobic bacterial processes were active in the reservoir. Calcites with high $\delta^{13} \mathrm{C}$ values $(>+15 \%$ ) record cementation of fractures from dissolved inorganic carbon (DIC) generated during bacterial methanogenesis. Calcites with low $\delta^{13} \mathrm{C}$ values $(<-32 \%)$ are solely associated with outcrop samples and record methane oxidation during cement precipitation. Fracture-fill calcite with $\delta^{13} \mathrm{C}$ values between -10 and $-30 \%$ can be attributed to variable organic matter oxidation pathways, methane oxidation, and carbonate rock buffering. Identification of ${ }^{13} \mathrm{C}$-rich calcite provides unambiguous evidence of biogenic methane generation and may be used to identify gas deposits in other sedimentary basins.

It is likely that repeated glacial advances and retreats exposed the Antrim Shale at the basin margin, enhanced meteoric recharge into the shallow part of the fractured reservoir, and initiated multiple episodes of bacterial methanogenesis and methanotrophic activity that were recorded in fracture-fill cements. The $\delta^{18} \mathrm{O}$ values in both formation waters and calcite cements increase with depth in the basin $(-12$ to $-4 \%$ SMOW, and +21 to $+27 \%$ PDB, respectively). Most fracture-fill cements from outcrop samples have $\delta^{13} \mathrm{C}$ values between -41 and $-15 \%$ PDB. In contrast, most cement in cores have $\delta^{13} \mathrm{C}$ values between +15 and $+34 \%$ PDB. Radiocarbon and ${ }^{230} \mathrm{Th}$ dating of fracture-fill calcite indicates that the calcite formed between 33 and $390 \mathrm{ka}$, well within the Pleistocene Epoch.
\end{abstract}

Key-words: Antrim Shale, fracture-fill calcite, methanogenesis

Received 11 November 2001; accepted 7 February 2002

Corresponding author: Lynn M. Walter, Department of Geological Sciences, University of Michigan, Ann Arbor MI 48109, USA.

E-mail: Imwalter@umich.edu. Tel: +734-763-4590. Fax: +734-763-4690.

Geofluids (2002) 2, 163-183

\section{INTRODUCTION}

The Late Devonian Antrim Shale is a self-sourced, unconventional gas reservoir in the Michigan Basin, USA. Significant amounts of variably saline water $(0-4 \mathrm{M} \mathrm{NaCl})$ are coproduced with economic quantities of natural gas from the Antrim Shale. This methane reservoir occurs within a sequence of organic-rich black shales interbedded with gray and green shales and carbonate units. The most important gas-producing region occurs in an arcuate band parallel to and within the subcropping Antrim Shale along the northern margin of the Michigan Basin (Fig. 1), commonly referred to as the Northern Producing Trend (NPT). Exploration on the western, eastern, and southern margins of the basin have shown promising results, whereas exploration in the more deeply buried Antrim Shale has proven unproductive (Walter et al. 1997; McIntosh et al. 2002). A list of well core and outcrop locations used in this study is presented in Table 1 and indicated on Fig. 1.

Gas, water, and rock samples from a variety of sites around the Michigan Basin were available for analysis during exploration of this gas play. In addition, surface samples were 


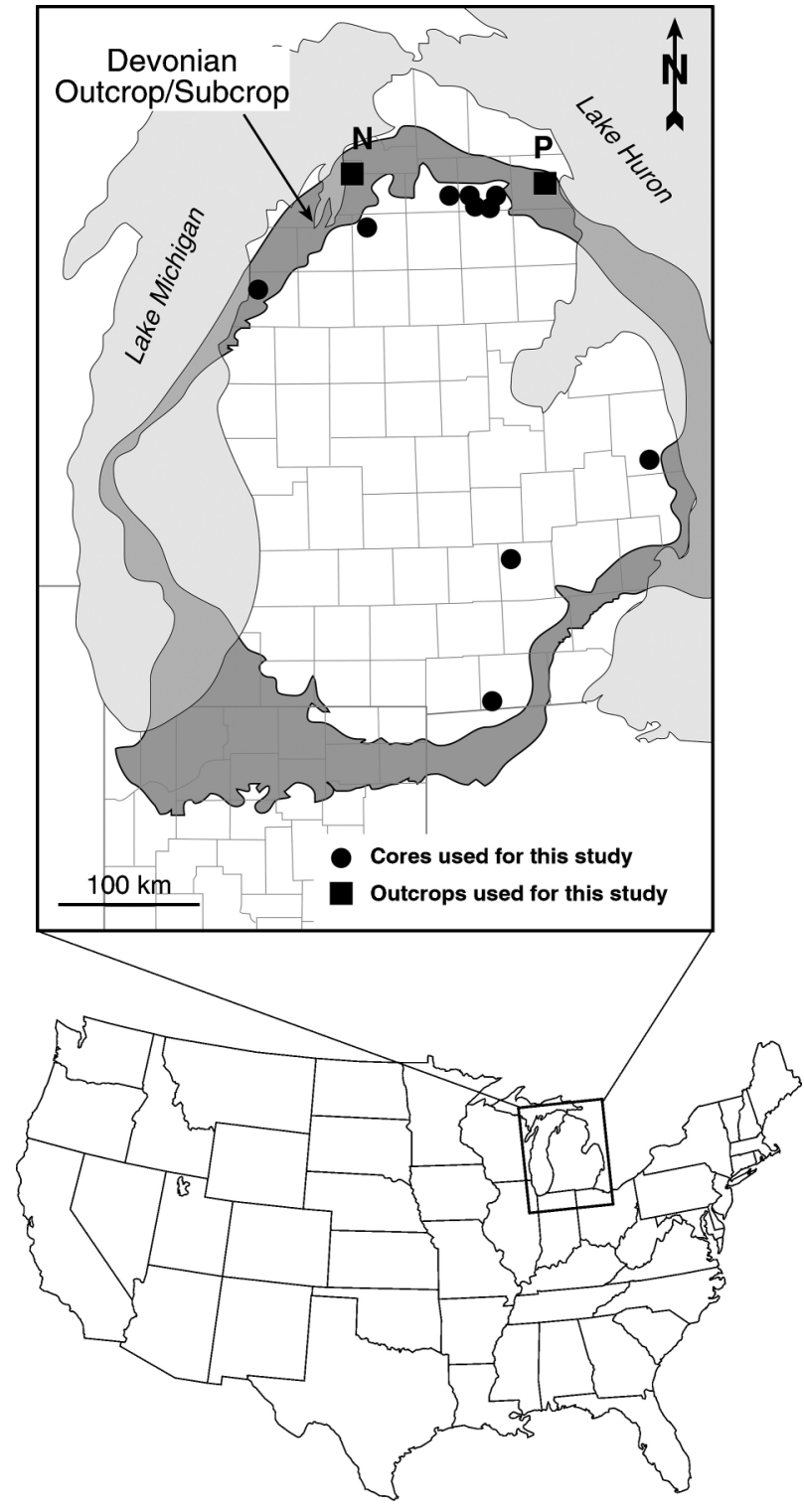

Fig. 1. Study location in Michigan, midcontinental USA. Shaded area is the subcrop/outcrop of the Devonian section in the Michigan Basin. Location of sites sampled include: well cores shown as dots; outcrops shown as solid squares. $\mathrm{N}$ is Norwood outcrop and $\mathrm{P}$ is Paxton Quarry. Figure modified from Martini et al. (1998). included from a quarry and an outcrop. Although natural gas production is unpredictable using conventional basin models, it is thought to be controlled in part by the well-developed naturally fractured network within the Antrim Shale. This paper explores the geochemical record in calcite cements that occur within this important fracture network. The isotopic composition of these calcite cements is closely linked to chemical parameters of formation fluids and provides constraints on gas generation and fluid migration pathways. The importance of structural fabric in the Antrim Shale and its physical proximity to areas of freshwater recharge are supported by the chemical and isotopic results. Fracture-fill calcite and associated water and gas may provide a diagnostic tool for identifying bacterial methanogenic processes in other, less well studied basinal settings or in ancient rocks influenced by microbial methane generation.

\section{GEOLOGIC FRAMEWORK}

The Antrim Shale subcrops below glacial sediment of variable thickness that was deposited during the waning stages of Pleistocene glaciation. Because the Michigan Basin is approximately circular, Devonian age outcrops and subcrops form an irregular ring around the basin margin (see Fig. 1). Present gas production is concentrated in the northern third of the basin, adjacent to and within the subcrop area, at relatively shallow depths $(<700 \mathrm{~m})$. The Antrim Shale is a highly fractured sequence dominated by two sets of orthogonal, high-angle fractures. 
Table 1 Location of outcrops and cores, and members sampled. Locations are shown on Fig. 1.

\begin{tabular}{|c|c|c|c|c|c|}
\hline & County & $\mathrm{Sec}$ & Twp & Rng & Member sampled \\
\hline \multicolumn{6}{|l|}{ Outcrops } \\
\hline Paxton Quarry & Alpena & 30 & $31 \mathrm{~N}$ & $7 \mathrm{E}$ & Norwood through Lachine \\
\hline Hycrude Core, adjacent to Paxton Quarry & Alpena & 30 & $31 \mathrm{~N}$ & $7 \mathrm{E}$ & Upper Antrim \& Norwood \\
\hline Norwood Outcrop & Charlevoix & 34 & $33 \mathrm{~N}$ & $9 \mathrm{~W}$ & Norwood \\
\hline \multicolumn{6}{|l|}{ Well Cores } \\
\hline Shell St. S. Branch 1-19 & Crawford & 19 & $25 \mathrm{~N}$ & $1 \mathrm{~W}$ & Lachine \\
\hline Shell St. Kalkaska 3-11 & Kalkaska & 11 & $28 \mathrm{~N}$ & $7 W$ & Lachine \& Paxton \\
\hline Yohe Thomas 1-28 & Lenawee & 28 & $8 \mathrm{~S}$ & $2 \mathrm{E}$ & Upper Antrim through Norwood \\
\hline Oil Joseph 3-23 & Manistee & 23 & $23 \mathrm{~N}$ & $16 \mathrm{~W}$ & Ellsworth through Traverse \\
\hline Shell St. Loud C2-31 & Montmorency & 31 & $29 N$ & $3 \mathrm{E}$ & Norwood, Lachine, Traverse \\
\hline Shell St. Loud D3-20 & Montmorency & 20 & $29 N$ & $3 \mathrm{E}$ & Upper Antrim \\
\hline Shell Caruso C2-28C & Montmorency & 28 & $29 N$ & $3 E$ & Lachine \\
\hline Trendwell Stevens Minerals 2-15 & Montmorency & 15 & $30 N$ & $3 E$ & Norwood \\
\hline Trendwell Thompson 1-8 & Montmorency & 8 & $30 \mathrm{~N}$ & $1 \mathrm{E}$ & Lachine \\
\hline Caruso $\mathrm{CH}-1$ \& $\mathrm{CH}-2$ & Montmorency & 28 & $29 N$ & $3 E$ & Ellsworth through Norwood \\
\hline Ward Lake Latuzcek B1-32 & Otsego & 32 & $30 N$ & $1 \mathrm{~W}$ & Squaw Bay Through Lachine \\
\hline Welch St. Chester \#18 & Otsego & 13 & $29 N$ & $2 \mathrm{~W}$ & Lachine \\
\hline Dow Erda \#103 & Sanilac & 8 & $9 N$ & $15 \mathrm{E}$ & Upper Antrim \\
\hline
\end{tabular}

\section{Stratigraphy}

In ascending order, the Upper Devonian sequence consists of the Squaw Bay Limestone (sometimes referred to as the Traverse Formation), the lower members of the Antrim Shale, the upper member of the Antrim Shale, the Ellsworth Shale, and in some locations, the Bedford Shale and Berea Sandstone (Fig. 2). The Upper Devonian section is separated from the underlying Middle Devonian Traverse Group and from the overlying Mississippian Sunbury Shale by regional unconformities (Fisher et al. 1988; Matthews 1993). The Antrim Shale is stratigraphically correlative with the Chattanooga and Ohio Shales of the Appalachian Basin, the New Albany Shale in the Illinois Basin, the Kettle Point Shale of western Ontario, and other upper Devonian black shales in North America and around the world. These rocks are known hydrocarbon sources or reservoirs.

In this study, we follow the nomenclature of Gutschick \& Sandberg (1991) and divide the Antrim Shale into four members: the Norwood; Paxton; Lachine; and Upper Antrim (Fig. 2). The Norwood Member is exposed in the Paxton Quarry on the northeast side of the Lower Peninsula of Michigan and on the northwestern edge of Michigan near the town of Norwood (Fig. 1; Table 1). Samples were collected from both sites for this study. The Norwood Member is a laminated, pyritic black shale with calcareous and dolomitic concretions that are commonly armored with an outer layer of pyrite and other iron sulphide minerals. The Norwood attains a maximum thickness of $12 \mathrm{~m}$ in the basin and varies between 8 and $9 \mathrm{~m}$ in the NPT of the Michigan Basin. The Norwood Member has an unusually high silica content for a black shale (Table 2; Hathon et al. 1980; Ruotsala 1980; Matthews 1993) and has total organic carbon contents (TOC) ranging from 10 to 24 weight percent (Table 2;
Matthews 1993). The margins of the Michigan Basin have never been deeply buried and the abundant organic matter present within black shales of the Lachine and Norwood Members is still immature based on low vitrinite reflectance values ( $\mathrm{R}_{\mathrm{o}}$ approximately 0.4; Rullkötter et al. 1992).

The Paxton Member is an interval of light gray, argillaceous limestone interbedded with dark and light gray calcareous shale. The Paxton Member attains a maximum thickness of $22 \mathrm{~m}$ in the basin and varies between 6 and $16 \mathrm{~m}$ in the NPT. The Paxton Member has much lower TOC contents than the Norwood, but comparable silica content (Table 2). Carbonate units within the member are dolomitic limestones. Samples of the Paxton Member were collected in the Paxton Quarry in northeast Michigan (Figs 1 and 2; Table 1).

The Lachine Member is also exposed in the Paxton Quarry and the Frasnian-Famennian boundary occurs in the lowermost part of this member. The Lachine consists of laminated, pyritic black shale alternating with greenish gray to dark gray shales and contains horizons with abundant concretions like those in the Norwood Member (Fig. 3). The Lachine has a maximum thickness of $30 \mathrm{~m}$ in the NPT, and thins westward to $12 \mathrm{~m}$ along the shore of Grand Traverse Bay. Like the Norwood Member, the Lachine Member has high silica and organic matter with low thermal maturity (Table 2; $\mathrm{R}_{\mathrm{o}}=$ 0.4-0.6; Matthews 1993; Rullkötter et al. 1992).

In the eastern half of the Michigan Basin, the Lachine Member is overlain by the Upper Antrim Member followed by the Ellsworth Shale. In the western half of the basin, the Ellsworth Shale overlies the Lachine Member. The Upper Antrim Member is late Famennian in age, consists of $7 \mathrm{~m}$ of black shale with rare concretions, and is capped by glacial drift at the Paxton Quarry (Fig. 3). The Upper Antrim Member has moderately high TOC, and is sometimes included in 


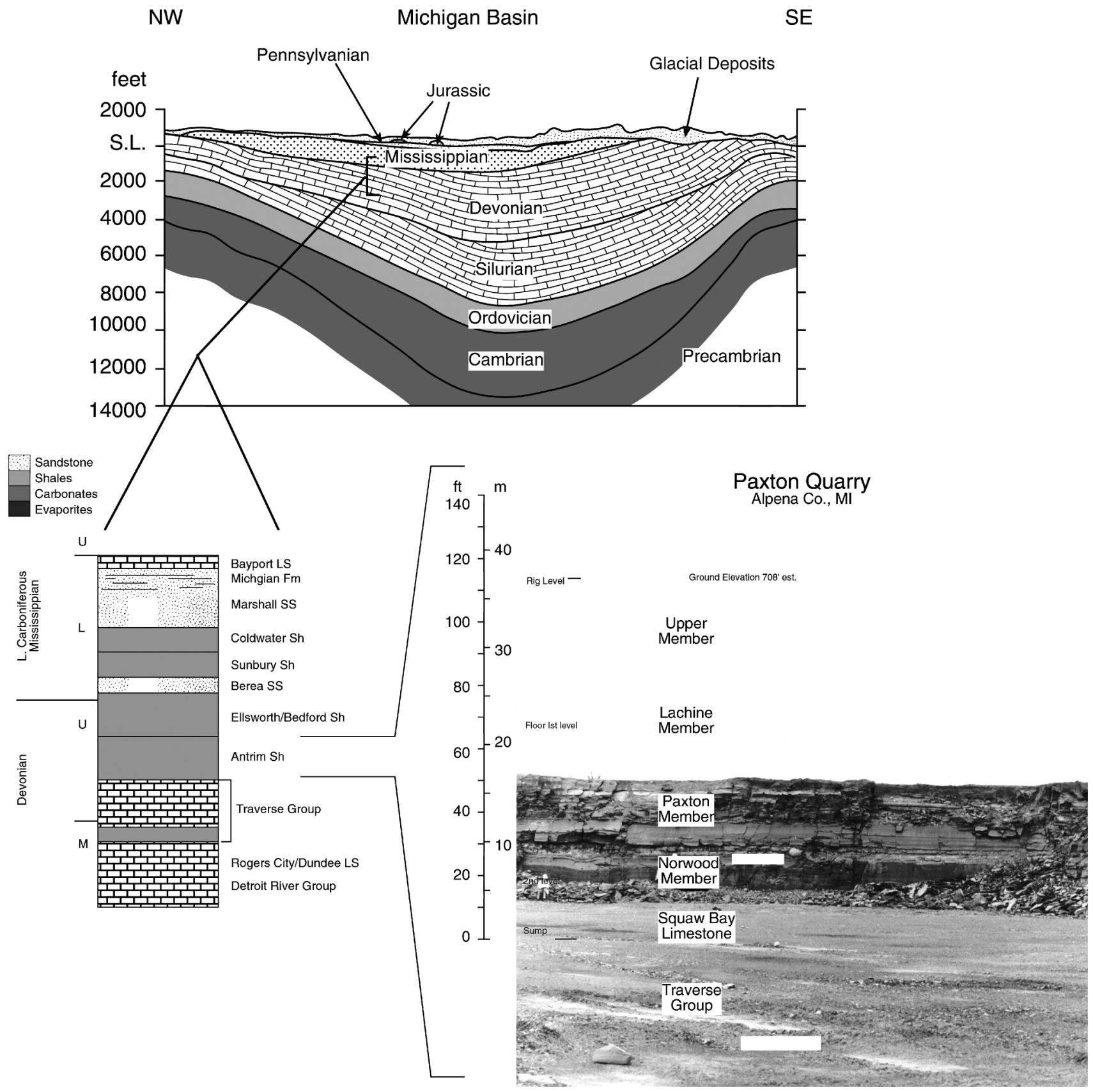

Fig. 2. The stratigraphic sequence of the Michigan Basin with expanded detail on Devono-Mississippian section and with details of the Upper Devonian Antrim Shale Section at the Paxton Quarry along with typical core log response (modified from Matthews 1993).

exploration for gas, although generally only the Lachine and Norwood Members are completed for gas production.

\section{Fracture geometry}

Fractures in the Antrim Shale have been described by many workers (Apotria et al. 1994; Caramanica 1994; Decker et al. 1992; Dellapenna 1991; Dellapenna \& Harrison 1993;Holst \& Foote 1981; Versical 1991; Walter et al. 1996). The descriptions of the dominant fracture sets are based on surface exposures of fractured Antrim Shale, as well as orientated cores and borehole-imaging logs. Most authors agree that there are two dominant sets of subvertical to vertical fractures, one orientated northwest and the other northeast, and a third set of inclined fractures that trend northeast and may be of importance to reservoir permeability. Locally important east-west fractures have also been noted (Holst \& Foote 1981; Apotria et al. 1994).

There is less agreement on the mechanism of formation of fractures. Holst \& Foote (1981) suggested that the northwest 
Table 2 Quartz and organic carbon content in lower members of the Antrim Shale, Paxton Quarry and Norwood Outcrop. Quartz (wt\%) determined by $\mathrm{XRF}^{*}$ and TOC by coulometry.

\begin{tabular}{|c|c|c|c|c|}
\hline Sample ID & Depth (m) & Lithology & $\begin{array}{l}\text { Quartz } \\
\text { (wt\%) }\end{array}$ & $\begin{array}{l}\text { Organic C } \\
\text { (wt\%) }\end{array}$ \\
\hline \multicolumn{5}{|c|}{ Paxton Quarry } \\
\hline \multicolumn{5}{|c|}{ Lachine Member } \\
\hline $\mathrm{LACH} 1$ & float & dark gray sh. & 41.1 & 7.2 \\
\hline $\mathrm{LACH} 2$ & float & light gray sh. & 24.4 & 0.3 \\
\hline LACH 3 & float & black sh. & 25.0 & 12.5 \\
\hline $\mathrm{LACH} 4$ & float & brown/gray sh. & 39.2 & 8.7 \\
\hline $\mathrm{LACH} 5$ & float & green/gray sh. & 20.6 & 0.4 \\
\hline LACH 6 & float & black sh. & 26.6 & 14.8 \\
\hline \multicolumn{5}{|c|}{ Paxton Member } \\
\hline PAX 1 & 0-0.4, Тор & gray sh. & 29.9 & 1.1 \\
\hline $\operatorname{PAX} 2$ & $0.4-0.56$ & carbonate & 7.2 & 0.3 \\
\hline $\operatorname{PAX} 3$ & $0.56-1.1$ & gray sh. & 12.9 & 0.4 \\
\hline PAX 4 & $1.1-1.7$ & gray sh. \& Is & 21.9 & 1.2 \\
\hline PAX 5 & $1.7-1.8$ & dolomitic Is & 5.6 & 0.9 \\
\hline PAX 6 & $1.8-2.2$ & gray sh. & 22.1 & 3.8 \\
\hline $\operatorname{PAX} 7$ & $2.2-2.4$ & limestone & 8.8 & 0.4 \\
\hline PAX 8 & $2.4-2.8$ & gray shale & 23.4 & 1.2 \\
\hline PAX 9 & $2.8-3.4$ & dark \& It. gray sh. & 25.2 & 3.5 \\
\hline PAX 10 & $3.4-3.7$ & limestone & 7.0 & 0.4 \\
\hline PAX 11 & $3.7-4.0$ & gray shale & 27.7 & 5.4 \\
\hline PAX 12 & $4.0-4.1$ & limestone & 7.4 & 0.5 \\
\hline PAX 13 & $4.1-4.4$ & dark gray sh. & 25.1 & 7.6 \\
\hline PAX 14 & 4.4-4.7, Base & gray sh. & 22.0 & 5.3 \\
\hline \multicolumn{5}{|c|}{ Norwood Member } \\
\hline NOR 0 & 0-0.4, Тор & dark gray sh. & 22.5 & 14.8 \\
\hline NOR 1 & $0.4-1.0$ & black, fissile sh. & 22.2 & 18.5 \\
\hline NOR 2 & $1.0-1.5$ & $\mathrm{br} / \mathrm{bL}$, massive/fissile & 21.9 & 18.3 \\
\hline NOR 3 & $1.5-1.9$ & $\mathrm{bl} / \mathrm{br}$ massive sh. & 19.9 & 24.0 \\
\hline NOR 4 & $1.9-2.3$ & $\mathrm{bl} / \mathrm{br}$ sh. & 22.2 & 20.5 \\
\hline NOR 5 & $2.3-2.8$ & bl/br sh. & 36.2 & 19.3 \\
\hline NOR 6 & 2.8-3.3, Base & br, massive sh. & 41.3 & 14.3 \\
\hline \multicolumn{5}{|c|}{ Norwood Outcrop } \\
\hline NOR 8 & $2 \mathrm{~m}$ above base & gray, massive & 27.6 & 11.4 \\
\hline NOR 7 & Base & gray, massive & 32.0 & 11.4 \\
\hline
\end{tabular}

*Analyses courtesy of Alden B. Carpenter, Chevron (modified from Walter et al. 1996). fracture set may be tectonic fractures genetically related to northwest trending folds in the Michigan Basin, but emphasized the regional nature of fracture trends in the Devonian across the northern basin. Versical (1991) added that the northwest fractures are parallel to the principal shortening directions on deformed calcite twins in the mid-continent that are interpreted to be related to Carboniferous palaeostresses (Craddock et al. 1993; Craddock \& van der Pluijm 1989).

In contrast, Apotria et al. (1994) proposed that the fractures are regional and not tectonic because they are widely distributed and independent of local structure. Based on stress history analysis and field observations, Apotria et al. (1994) concluded that the correlation between organic rich intervals and good fracture development commonly observed in the Antrim Shale is not fortuitous. They argued that the northwest fracture set formed as a result of natural hydraulic fracturing associated with maturation of organic matter during the maximum burial of the Antrim Shale (c. $250 \mathrm{Ma}$ ). These fractures would be orientated relative to the regional stress field imposed by the Alleghenian Orogeny. The present-day direction of maximum compressive stress in Northeastern North America is to the ENE (Plumb \& Cox 1987; Zoback \& Zoback 1989; Gross \& Engelder 1991). Based on this information, the northeast fracture set in the Antrim Shale is presently more likely to be open than the northwest set.

\section{HYDROGEOCHEMISTRY OF THE ANTRIM SHALE}

\section{Water chemistry}

The geochemistry of water and gas samples from Antrim Shale reservoirs is presented in detail elsewhere and provides important constraints on the work described in this study (Martini et al. 1996, 1998; Walter et al. 1996, 1997; McIntosh et al. 2002). In brief, spatial distributions of chemical and isotopic compositions within formation waters exhibit strong regional trends. Wells located near or within 

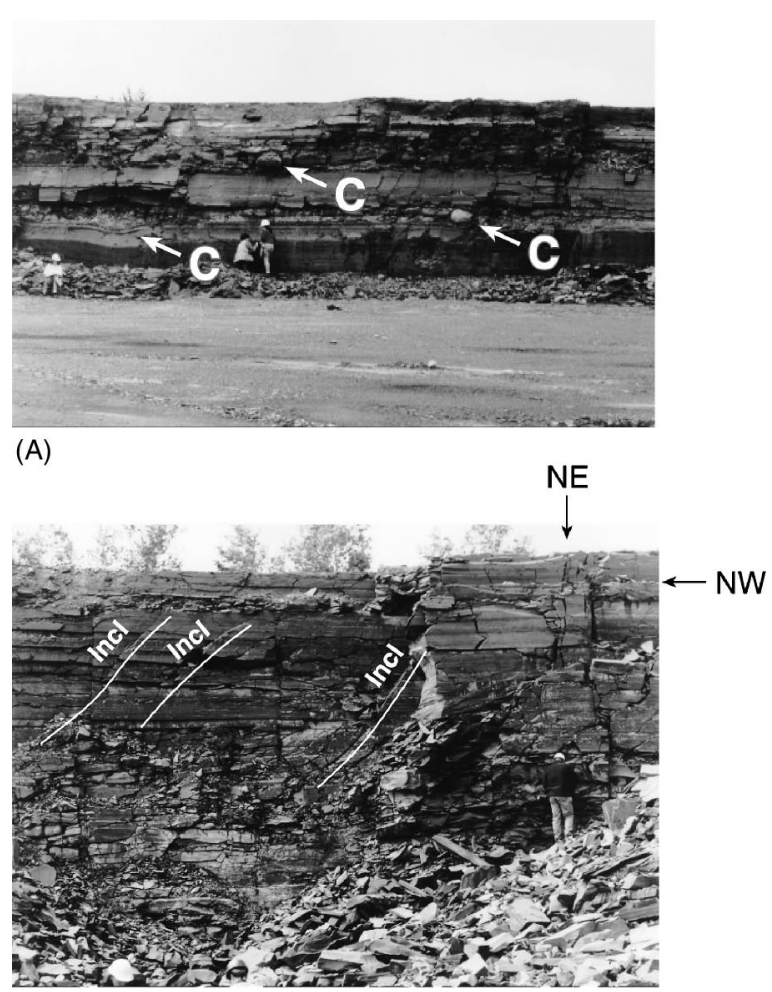

(C)
PAXTON QUARRY: MIDDLE BENCH

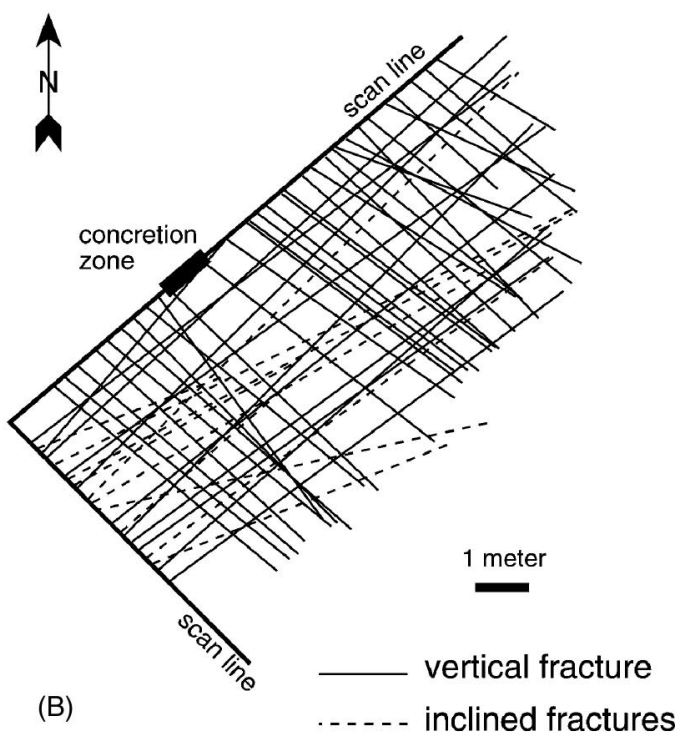

Fig. 3. (A) Paxton Quarry, upper bench, Lachine Member. Large spherical concretions in quarry wall indicated by $C$ with arrow. The exposed face trends northwest and is cut by vertical northeast fractures and steeply dipping northeast fractures. (B) A diagram based on several scan lines of fracture measurements from the Lachine Member in the middle bench of the Paxton Quarry. Inclined fractures shown by dashed lines. Note that the large concretion in the northeast trending quarry wall exerts a shadow effect on the frequency of large, through-going fractures. Figure modified from Walter et al. (1996). (C) Three fracture sets are visible in this photograph from the upper bench of the Paxton Quarry. The exposed face parallel to the plane of view is a northwest trending fracture. Northeast fractures are vertical joints cutting the northwest face, and inclined fractures with northeast trends (indicated by white lines) are also visible.

the subcrop area produce water with low salinities $(<0.1 \mathrm{M}$ $\mathrm{Cl}^{-}$), high concentrations of dissolved inorganic carbon (DIC; $40-60 \mathrm{~mm})$, high carbon isotope values $\left(\delta^{13} \mathrm{C}_{\mathrm{DIC}}\right.$ approximately +26 to $+30 \%$ PDB), and low $\mathrm{H}_{2} \mathrm{O}$ isotope values $\quad\left(\delta^{18} \mathrm{O}\right.$ approximately $\quad-15 \%, \quad \delta \mathrm{D}$ approximately $-90 \%$ SMOW). Wells located in the deeper, basinward part of the reservoir produce water with high salinities (up to $5 \mathrm{M}$ $\mathrm{Cl}^{-}$), lower DIC concentrations $(6-10 \mathrm{~mm})$, lower carbon isotope values $\left(\delta^{13} \mathrm{C}_{\mathrm{DIC}}=+22\right.$ to $\left.+25 \% \mathrm{PDB}\right)$ and higher $\mathrm{H}_{2} \mathrm{O}$ isotope values $\left(\delta^{18} \mathrm{O}=-6 \%, \delta \mathrm{D}=-35 \%\right.$ sMOW $)$. Complex trends in chemical and isotopic compositions of brines from the Antrim Shale appear to highlight pathways for fluid flow and mixing between the shallow and deeper part of the reservoir. These patterns suggest two sources of water: (i) a high-salinity, ${ }^{18} \mathrm{O}$ and $\mathrm{D}$-enriched basinal brine component; and (ii) a dilute water with $\delta^{18} \mathrm{O}$ and $\delta \mathrm{D}$ values that suggest recharge from a cooler climate than present surface conditions.

Distribution of dilute formation waters within the Antrim Shale implies that recharge is controlled by fracture trends in the reservoir and is focused along glacial gouge zones in the subcrop of the Antrim Shale (Walter et al. 1996). Radiocarbon analyses of DIC from shallow Antrim Shale formation waters yield corrected recharge times of 6000-27 000 years before present (Martini et al. 1996, 1998). Taken together with the $\delta \mathrm{D}$ and $\delta^{18} \mathrm{O}$ values of formation water, these data indicate recharge of water during the Quaternary when surface temperatures were cooler than today.

\section{Gas chemistry}

The chemical and isotopic composition of gas from the Antrim Shale, like the associated water chemistry, implies a complex, mixed source history. Although carbon isotopic compositions of methane $(-48$ to $-58 \%$ ) fall between thermogenic and microbial methane, the extremely high $\delta^{13} \mathrm{C}$ values of coproduced $\mathrm{CO}_{2(\mathrm{~g})}(+22 \%)$ and DIC in formation waters require bacterial mediation (Coleman et al. 1995; Martini et al. 1996, 1998). However, it is the positive correlation between the $\delta \mathrm{D}$ in coproduced $\mathrm{CH}_{4}$ and formation waters reported in Martini et al. (1996, 1998, in review) that is the strongest evidence for methane generation via $\mathrm{CO}_{2}$ reduction occurring within the reservoir. This relationship between the $\delta \mathrm{D}_{\mathrm{H} 2 \mathrm{O}}$ and $\delta \mathrm{D}_{\mathrm{CH} 4}$ values suggests that the timing of microbial gas generation and the emplacement of the present formation water are linked. The problem under 
consideration now is the possible genetic link between calcite, which has filled fractures in this young gas reservoir, and formation fluids described previously.

\section{METHODS}

\section{Field measurement and sample collection}

Fracture attitude and spacing were measured in the Norwood and Lachine Members of the Antrim Shale at three levels within the Paxton Quarry in Alpena County and at a Lake Michigan shoreline outcrop of the Norwood Member where it is exposed about $1 \mathrm{~km}$ south of the town of Norwood (Fig. 1). Spacing between large, through-going fractures was tabulated along orientated transects. A summary of fracture frequency, together with dominant fracture attitudes, is presented in Table 3.
Collection of calcite from the fractures was accomplished in several ways. Most samples were thin coatings on black shale fracture walls that required a small blade to separate the cement from the wall rock. At the Norwood outcrop, most fractures were filled with a thick vein of calcite and samples were retrieved using a rock chisel and hammer to remove both vein and some wall rock samples. In core samples some specimens were highly friable, similar to cements in outcrop, and calcite was removed from these fracture faces with a knife. In many intervals, fracture cements were intact and small chips were cut for isotopic sampling and thin section preparation.

Samples from cores and outcrop were prepared for petrographic examination and isotopic subsampling by polishing cut surfaces, and, where necessary, staining with Alizarin Red $S$ and potassium ferricyanide to distinguish calcite from dolomite and to identify ferroan cements in concretions
Table 3 Spacing of large, through-going fractures, summarized from field measurements at Paxton Quarry and the Norwood outcrop. Details tabulated in Walter et al. (1996).

\begin{tabular}{|c|c|c|c|c|}
\hline $\begin{array}{l}\text { Transect } \\
\text { orientation }\end{array}$ & $\begin{array}{l}75-90^{\circ} \text { Dip } \\
\text { NE fracture } \\
\dagger \text { frequency }\end{array}$ & $\begin{array}{l}75-90^{\circ} \text { Dip } \\
\text { NW fracture } \\
\text { †frequency }\end{array}$ & $\begin{array}{l}\text { Member } \\
\text { sampled }\end{array}$ & Comments \\
\hline \multicolumn{5}{|c|}{ †Paxton Quarry } \\
\hline \multicolumn{5}{|c|}{ Upper quarry } \\
\hline $10^{\circ}$ & 2.74 & 1.5 & Lachine & 2 segments of \\
\hline $10^{\circ}$ & 1.2 & 1.8 & Lachine & same transect \\
\hline $142^{\circ}$ & 1.94 & & Lachine & $\mathrm{NE}$ inclined spacing $=1.78$ \\
\hline $231^{\circ}$ & & 1.9 & Lachine & \\
\hline $208^{\circ}$ & & 1.01 & Lachine & \\
\hline $306^{\circ}$ & 1.14 & & Lachine & \\
\hline $310^{\circ}$ & 1.98 & & Lachine & \\
\hline $311^{\circ}$ & 1.95 & & Lachine & \\
\hline $316^{\circ}$ & 2.62 & & Lachine & \\
\hline $355^{\circ}$ & 1.1 & 1.1 & Lachine & 3 interrupted \\
\hline $355^{\circ}$ & 0.78 & 0.78 & Lachine & segments of \\
\hline $355^{\circ}$ & 1.69 & 1.27 & Lachine & same transect \\
\hline \multicolumn{5}{|c|}{ Middle bench } \\
\hline $140^{\circ}$ & 1.63 & & Lachine & \\
\hline $235^{\circ}$ & & 1.8 & Lachine & \\
\hline $236^{\circ}$ & & 1.5 & Lachine & \\
\hline $236^{\circ}$ & & 2.25 & Lachine & \\
\hline \multicolumn{5}{|c|}{ Lower quarry } \\
\hline $65^{\circ}$ & 1.17 & 0.97 & Norwood & \\
\hline $83^{\circ}$ & 0.98 & 1.97 & Norwood & \\
\hline $293^{\circ}$ & 1.04 & & Norwood & \\
\hline $316^{\circ}$ & 0.58 & & Norwood & \\
\hline $340^{\circ}$ & 0.39 & & Norwood & \\
\hline \multicolumn{5}{|c|}{$\ddagger$ Norwood Outcrop } \\
\hline $336^{\circ}$ & 1.22 & & Norwood & \\
\hline $344^{\circ}$ & 1.63 & & Norwood & \\
\hline $336^{\circ}$ & 1.63 & & Norwood & \\
\hline $338^{\circ}$ & 1.63 & & Norwood & \\
\hline $338^{\circ}$ & 2.44 & & Norwood & \\
\hline $338^{\circ}$ & 1.13 & & Norwood & \\
\hline $334^{\circ}$ & 4.88 & & Norwood & \\
\hline $332^{\circ}$ & 1.53 & & Norwood & \\
\hline
\end{tabular}

*Data from quarry measured by J. A. Richards, A. M. Martini, W. Higgs and C. S. Stearns. †Scan length (in $\mathrm{m}$ )/number of fractures. $\ddagger$ Data from outcrop measured by J. M. Budai and A. M. Martini. 
(Evamy 1963). Thin sections and chips were examined in cathodoluminescence using a Nuclide Luminoscope, operating at $10-12 \mathrm{kV}$ with a sample current of 100 milliamps.

A microscope mounted dental drill was used to sample carbonate components from chips and slabs of rock (Dettman \& Lohmann 1995). Drilled sample sites are $0.5 \mathrm{~mm}$ in diameter. In some cases, fracture cements were fine, friable, pieces of calcite removed from fracture walls in the field. These were ground with a mortar and pestle and then analyzed.

\section{Stable isotope analyses}

Stable isotopes of oxygen and carbon in carbonate samples were measured in the Stable Isotope Laboratory at the University of Michigan. All samples are placed in small stainless steel boats and roasted under vacuum at $380{ }^{\circ} \mathrm{C}$ for $1 \mathrm{~h}$ to remove volatile components. Carbon and oxygen isotopes were determined in calcite and dolomite samples using an automated sample preparation on-line Kiel device attached to a Finnigan Mat 251 ratio mass spectrometer. Calcite and dolomite samples were reacted with anhydrous phosphoric acid at $74{ }^{\circ} \mathrm{C}$, for $6 \mathrm{~min}$ and $10 \mathrm{~min}$, respectively, and results compared to the internal lab standard gas, which is calibrated to the NBS 20 Salenhofen limestone standard. Measured precision is maintained at better than $0.1 \%$ for both $\delta^{13} \mathrm{C}$ and $\delta^{18} \mathrm{O}$.

The core and outcrop samples for the determination of $\delta^{13} \mathrm{C}$ of organic matter in black shales were prepared as follows: $20-40 \mathrm{mg}$ of previously acidified ground sample was mixed with cupric oxide in pyrex tubes, roasted at $480^{\circ} \mathrm{C}$ for $\mathrm{l} \mathrm{h}$, and the evolved $\mathrm{CO}_{2}$ gas cryogenically separated. Samples were analysed on a Finnigan MAT Delta $S$ mass spectrometer in the Stable Isotope Laboratory at the University of Michigan. NBS $22\left(\delta^{13} \mathrm{C}=-29.7 \%\right.$ PDB $)$ was used as a standard.

\section{Related geochemical analyses}

The silica content of black shales was measured using an X-ray fluorescence spectrometer (XRF) at the Chevron Petroleum and Technology Company in La Habra, California. Total organic carbon was determined by combusting preacidified samples and measuring the evolved $\mathrm{CO}_{2}$ coulometrically, in the Experimental and Analytical Geochemistry Laboratory at the University of Michigan and also at Chevron.

Radiocarbon measurements of calcite were made by accelerator mass spectrometry (AMS) at the University of Arizona. Because radiocarbon analyses required larger calcite samples than the $\delta^{13} \mathrm{C}$ and $\delta^{18} \mathrm{O}$ analyses, the ${ }^{14} \mathrm{C}$ was measured on larger samples from the same fracture-fill calcite. $\mathrm{A} \delta^{13} \mathrm{C}$ value was determined on all sample splits analyzed for ${ }^{14} \mathrm{C}$. Uranium and thorium isotopic compositions were measured on a subset of calcite samples at the University of Minnesota Isotope Laboratory following the methods of Edwards et al. (1987).

\section{RESULTS}

\section{Fracture occurrence and description}

The best fracture development in the Antrim Shale at Paxton Quarry occurs in the organic-rich black shales of the Norwood and Lachine Members. The largest fractures extend through the Norwood and Lachine Members, but terminate at the contacts with the light gray shales of the intervening Paxton Member. Two sets of vertical to subvertical joints (dips $>85^{\circ}$ ), one striking northwesterly and one northeasterly, are the dominant fracture sets in the Paxton Quarry and the Norwood outcrop (Fig. 3). Where large concretions are present, fractures are more widely spaced and trends diverge away from the concretion (Fig. 3a).

A third set of large fractures strikes northeasterly with southeasterly dips, usually in the range of $55-70^{\circ}$. In several locations, both in the quarry and at the outcrop, mechanical interactions between individual fractures can be observed. These fractures become steeper and terminate as they approach a vertical fracture (Fig. 3c). This kind of joint interference is common in naturally forming joints (Engelder 1993; Pollard \& Aydin 1988; ). There are abundant smaller scale fractures as well. However, based on the link between natural gas production, fluid flow and the major throughgoing fracture network within the Antrim Shale, sample collection focused on fracture-fill calcite from the largest fractures where possible. Timing of the high angle northeast and northwest sets is probably synchronous based on mutually crosscutting relationships observed at both the quarry and outcrop exposures.

The second set of inclined, northeast-trending fractures are inferred to be younger than the vertical joints due to the change in geometry of fracture faces near vertical joints. Measurements of these three fracture sets along scan-lines in the quarry are shown in a diagram of two quarry walls (Fig. 3b). A summary of field measurements from both the outcrop and quarry is presented in Table 3 .

At the outcrop south of Norwood, Michigan, along the Lake Michigan shoreline, only the Norwood Member of the Antrim Shale is preserved (Kesling et al. 1976). Fracture attitude and length are similar to those measured in the Paxton Quarry (Table 3). Fractures are well exposed in 3-dimensions due to wave cut benches immediately beneath a northwest trending vertical cliff of the Norwood Shale. Due to the orientation of the exposed wall, the northeast trending set of fractures is well represented, but the northwest set is only exposed on the basal surface of the submerged bench.

The largest fractures in cores are high angle and generally have straight margins. Smaller scale, low angle and bedding parallel fractures are also present. Studies based on fracture imaging logs indicate that the buried Antrim section hosts a network of high angle fractures similar to those exposed at the surface (Caramanica 1994; Walter et al. 1996). Completion 
practices used in the Antrim Shale include artificial fracturing to open existing natural fractures (Zuber 1995), making the dominant orientations of fractures an important component of exploration strategies.

\section{Fracture-fill calcite}

Cements within fractures range from coarse-grained calcite mosaics that completely seal fractures, to microcrystalline calcite coatings that partially seal fractures. At the Paxton Quarry, cements are thin, microcrystalline to fine-grained calcite coating on fracture walls (Fig. 4A). There was no petrographic evidence of multiple cementation events within this sparsely cemented group of fractures. A small diameter core taken adjacent to the Paxton Quarry recovered most of the section and also the upper part of the underlying Traverse Group. Unfortunately, the fractures intersected were largely low angle, smaller scale fractures rather than the large, through-going fractures from which calcite cement was sampled in the quarry. Very minor calcite cement partly coats some of the core fractures. The surface texture of the cements is fine, granular and indistinguishable from cements observed and sampled in the quarry. This similarity in cementation between the core and the exposed quarry walls suggest that: (i) evidence of modern surface weathering is not greater in samples from exposed quarry walls than in subsurface samples; and (ii) calcite cements in a broad range of fracture scales and attitudes may be genetically related.

In contrast to exposures in the quarry, northeast and northwest fractures at the Norwood outcrop host thick calcite cement fillings (up to $7 \mathrm{~mm}$ in thickness) that are easily seen under and at lake level, but are poorly preserved in the outcrop a meter above lake level (Fig. 4b). In the outcrop above lake level, cements are thinner and some are encrusted with a coating of secondary weathering products. In fractures that can be traced out into the sublake bench, well preserved, coarse calcite cements may include fine iron-sulphide crystals along the fracture margins and commonly contain thin slivers of wall rock, suggesting that fracturing and cementation were intermittent. Figure 4C illustrates diagrammatically the various fracture fill orientations and stable isotope values. The calcite cements within fractures from the two outcrop sites have patchy variations in luminescence that range from dull to bright orange, but are not systematically zoned when examined in cathodoluminescence. The most ferroan cements are nonluminescent. Luminescent variations do not appear to be related to either fracture orientation or location of sample.

Cementation is not common in core fractures. Thin layers of calcite occur irregularly on one or both walls of vertical fractures. Small inclined fractures and bedding-parallel fractures are more completely cemented than vertical fractures. Fracture-fill cements from a number of well cores were examined and appeared petrographically similar to cements

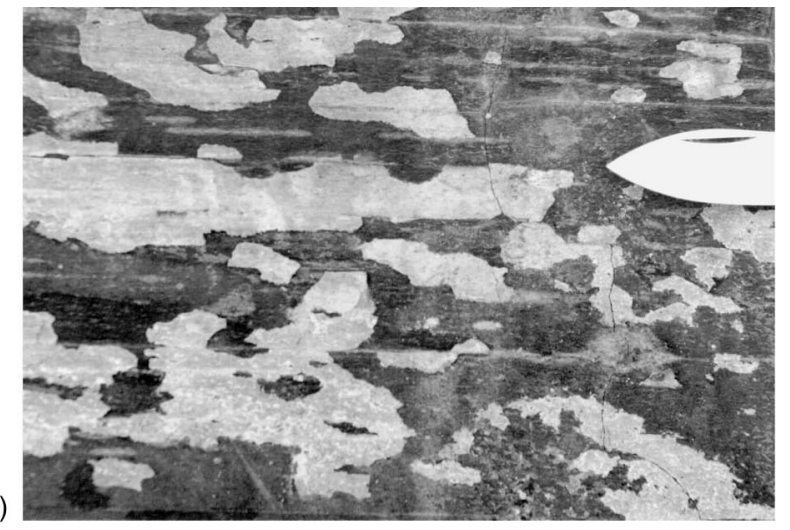

(B)

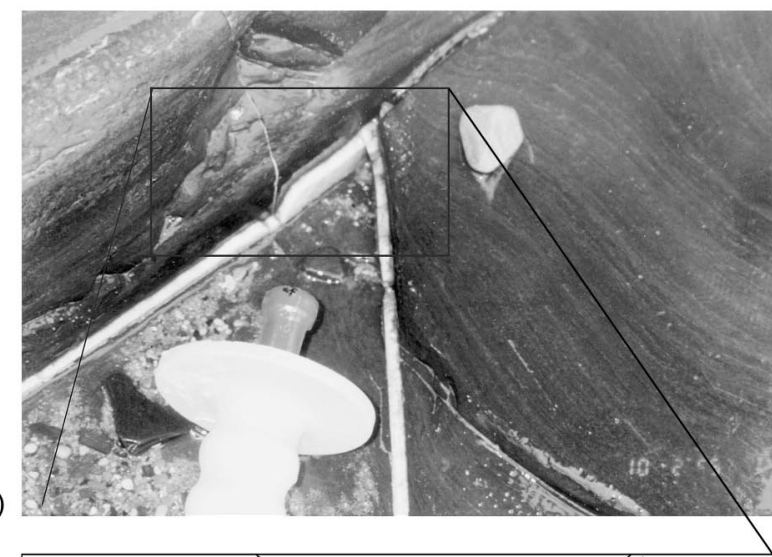

(C)

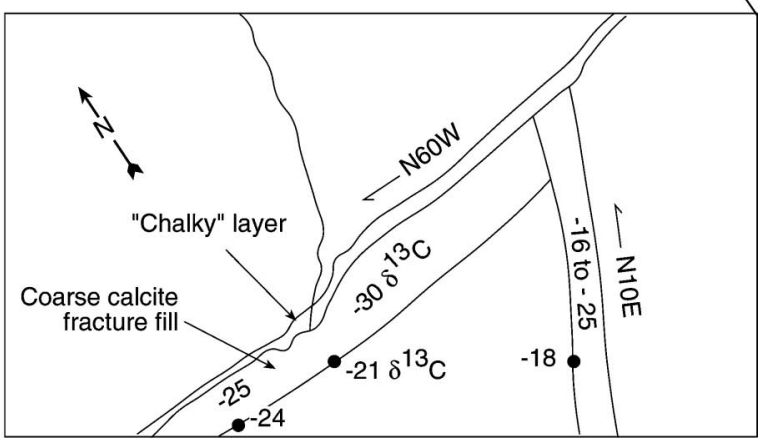

Fig. 4. (A) Thin, irregular patches of calcite cement on a fracture face at the Norwood outcrop. Tip of a small pocket knife blade for scale. (B) Northeast and northwest fractures filled with thick calcite veins at the Norwood outcrop. This site is in the shallow wave zone, just below cliffs of the Norwood Member of the Antrim Shale. The handle of a rock chisel, about $10 \mathrm{~cm}$ long, is shown for scale. (C) Diagrammatic view of crosscutting calcite fractures having different stable isotope compositions. Carbon isotope values in \%o PDB.

studied from outcrop samples. Calcite appeared homogenous under microscopic examination. Fractures with the thickest calcite fill were coarser-grained than the fine to microcrystalline cement in thin fracture fill. Commonly, a small amount of pyrite had intergrown with calcite in core fractures, either as part of the vein or as discrete nodules. Fine pieces of wall rock are entrained within fracture cement (Fig. 5A,B). In thin section, calcite has patchy dull to bright orange luminescence, 


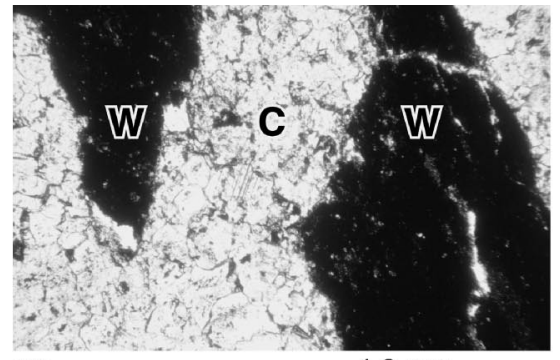

(A)

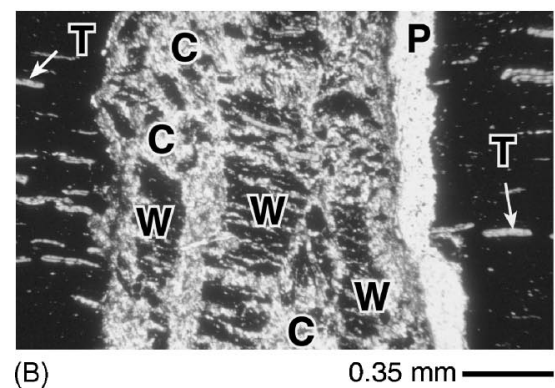

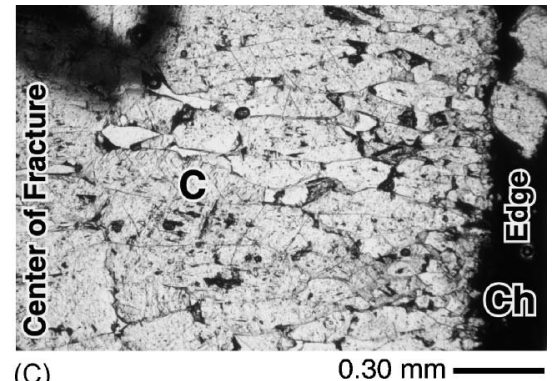

(C)

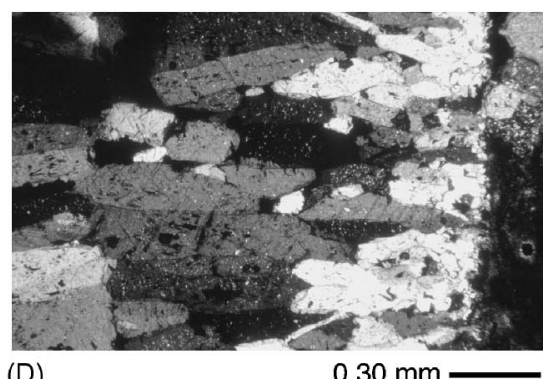

Fig. 5. Photomicrographs of fractures with calcite fillings. (A) Coarse calcite cement within a fracture trending N76 ${ }^{\circ}$ from the Norwood outcrop, Norwood Member of the Antrim Shale. Complete fracture fill is $6 \mathrm{~mm}$ in width. Dark areas are slivers of black shale wall rock entrained in the vein. Long dimension of field of view is $3 \mathrm{~mm}$. (B) Fine-grained calcite (c) and fragments of wall rock ( $w$ ) within a fracture in a core sample (approximately $480 \mathrm{~m}$ depth ( $1437 \mathrm{ft}$ )). Bright platelets are tasmanites $(t)$ orientated parallel to shale bedding. Clear strip $(p)$ parallel to fracture is pore space caused by thin section preparation. This fracture is high angle, N45E, and $1 \mathrm{~mm}$ wide. Field of view is $3 \mathrm{~mm}$ wide. (C) Plane light photomicrograph of fracture margin and coarse, bladed calcite (c) fill from an outcrop sample. Fracture trend is $\mathrm{N}^{\circ} 3^{\circ} \mathrm{E}$ and calcite fill is $5 \mathrm{~mm}$ wide. Between the coarse calcite and wall rock margin, a thin layer of chalky calcite (ch) looks dark in the photo. Field of view is $2.5 \mathrm{~mm}$ wide. (D) Same view as in 5C, under cross-polarized light. Partial extinction illustrates calcite crystal orientation, which is normal to fracture wall.

with rare later stage nonluminescent calcite crosscutting veins. As with outcrop samples, cathodoluminescent variations are not clearly related to stratigraphic position, geographical location, or isotopic composition (as discussed below).

A coarse zoning of crystal fabric and color is present in the thickest veins. On one or both margins of vein fill there is commonly a thin layer of chalky, microcrystalline calcite (Fig. 5C,D). In thin section and polished chips an irregular, corroded contact is visible between the chalky layer and the coarse calcite that fills most of the fracture. This suggests that the chalky coating formed subsequent to the main, coarsegrained calcite fill in the fracture and has etched and replaced the fracture wall margins of coarser crystals. The coarse calcite that comprises most of the fracture fill ranges from prismatic and scalenohedral to equant in crystal fabric. Where cements are prismatic to scalenohedral, the long axes of the calcite crystals are normal to the fracture wall (Fig. 5D).

The highly weathered appearance of thin cement layers on the Norwood outcrop walls, especially when compared to calcite cement in the same fracture at lake level, strongly suggests that these fracture fills have not preserved an accurate record of original cement chemistry. The chalky coating that occurs only on fracture fills presently under lake water may record periodic exposure and surficial weathering of the shale outcrop during times of lowered lake levels, a common event throughout the Pleistocene and Holocene. The coarse- grained calcite fills in fractures at lake level, when chalky margins are excluded, are the best record of geochemical conditions during original fracture cementation.

\section{Isotopic record in the Antrim Shale}

Due to the very low matrix porosity of the Antrim Shale, it can be inferred that formation fluids and gases moved preferentially through the fracture network that crosscut the shale. Calcite cementation provides a record of that fluid's composition. Petrographic study and stable isotopic analyses of 13 well cores and two outcrop locations (Table 1 ) reveal a history of fracture-fill calcite that varies widely in $\delta^{13} \mathrm{C}$ values, suggesting a link to microbial processes during cementation.

The average composition of limestone units within the Paxton Member and in the underlying Squaw Bay Limestone were used to estimate the potential contribution of wall rock carbonate to fracture-fill calcite. The $\delta^{13} \mathrm{C}$ of organic carbon, measured in several black shale samples from the reservoir, is -29 to $-30 \%$ PDB (Appendix), typical of Late Devonian organic matter globally (Galimov et al. 1975; Galimov 1980). Carbonate cements within large concretions and calcite cements lining through-going fractures and smaller scale fractures in both surface exposures and cores were sampled for this study. Coarsely crystalline calcite and dolomite cements are common within large concretions and both are 

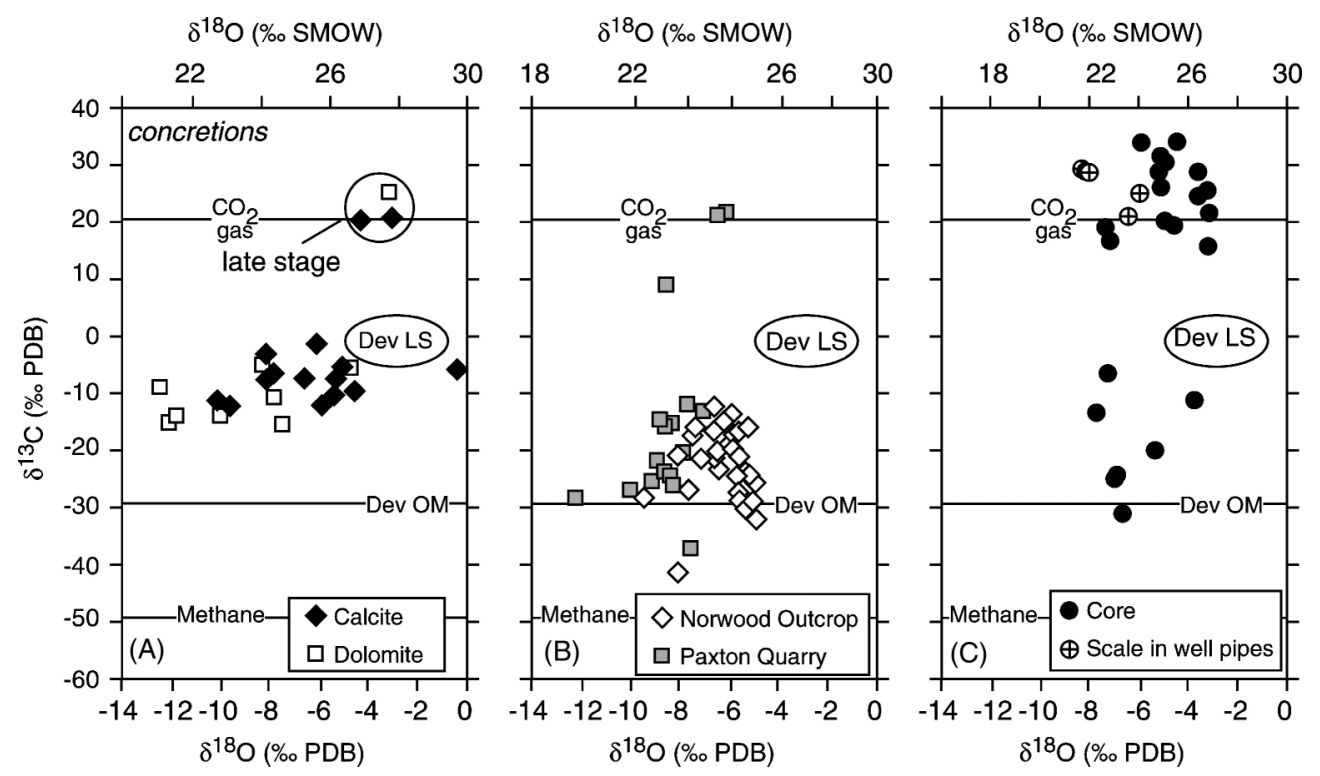

Fig. 6. Stable isotopes ( $\delta^{18} \mathrm{O} \%$ PDB and SMOW, $\delta^{13} \mathrm{C} \%$ PDB) in (A) concretions, (B) outcrop and quarry samples, and (C) well core and scale samples. Horizontal lines indicate the $\delta^{13} \mathrm{C}$ of methane and $\mathrm{CO}_{2}$ produced from the Antrim Shale and the $\delta^{13} \mathrm{C}$ of organic matter (Dev OM) from black shales of the Lachine and Norwood Members. The field indicated as Dev Ls was determined by analyses of Devonian limestones, within the Antrim Shale and from the underlying middle Devonian Traverse Group. (A) Cements within large concretions from the Lachine Member of the Antrim Shale. The first cements are generally calcite, followed by several generations of coarse dolomite cements. Rare, final stage carbonate cements ('late stage') have high $\delta^{13} \mathrm{C}$ values, similar to those in fractures. (B) Calcite in fractures from outcrop and quarry locations. (C) Calcite in core fractures and calcite scale samples taken from well pipes of producing gas wells in the Antrim Shale.

ferroan, based on staining with potassium ferricyanide (Evamy 1963). Isotopic study of cements from several concretions indicates that the first generations of calcite and dolomite cements have moderately low isotopic values (calcite -1 to $-12 \delta^{13} \mathrm{C} \%,-5$ to $-10 \delta^{18} \mathrm{O} \% \mathrm{PDB}$; dolomite -12 to $-15 \delta^{13} \mathrm{C} \%$, -7.5 to $-12.5 \delta^{18} \mathrm{O} \%$ PDB; Fig. $6 \mathrm{~A}$; Appendix). Rare, late-stage calcite and dolomite cements in concretions have high carbon and oxygen values $\left(\delta^{13} \mathrm{C}=+22 \%\right.$ o, $\delta^{18} \mathrm{O}=-4 \%$ PDB; Fig. $\left.6 \mathrm{~A}\right)$.

These values are similar to one population of fracture cements described below, which may indicate that some concretion fractures were open to fluid flow during later diagenetic stages in the Antrim Shale or that similar biogeochemical reactions have occurred within individual concretions. A previous petrologic study of concretions in the Antrim Shale concluded that they formed very early in the diagenetic history of the unit (Wardlaw 1981). However, in a study of similar concretions from the Middle Devonian Marcellus Shale in central New York, Siegel et al. (1987) inferred that the complicated cementation sequence recorded early to late stage mineralization in that unit, including isotopic evidence of methane fermentation during carbonate precipitation.

\section{Carbon isotopes in fracture-fill cements}

There is an unusually broad range of carbon isotopic compositions in fracture-fill cements from the NPT of the Antrim
Shale (Appendix). There is nearly a continuum of $\delta^{13} \mathrm{C}$ values, from extremely low $(-42 \%$ ) to markedly high $(+34 \%$ o $)$. Figure 6 shows the range in carbon and oxygen isotopic values for carbonate concretions and from fracture-fill calcite cements. The isotopic compositions obtained from concretion samples (Fig. 6A) tend to be the least extreme. Many concretions have isotopic values close to that of Devonian-age limestone. This is consistent with an origin relatively early in diagenesis.

Fracture-fill calcites with the highest and lowest values are the two groups that require special consideration (see Figs $6 \mathrm{~B}, \mathrm{C})$. The first population has high carbon isotope values $\left(\delta^{13} \mathrm{C}=+15\right.$ to $+31 \%$ ), whereas the second group has unusually low carbon values $\left(\delta^{13} \mathrm{C}=-10\right.$ to $-42 \%$ PDB). The oxygen isotope values are similar in both groups $\left(\delta^{18} \mathrm{O}=-3.0\right.$ to $\left.-9.0 \% \mathrm{PDB}\right)$. Calcite in the first population has carbon isotope values comparable to those in modern calcite scale forming within well pipes carrying brines and gas from the Antrim Shale to the surface $\left(\delta^{13} \mathrm{C}=+21\right.$ to $+29 \%$; Fig. 6C). The $\delta^{13} \mathrm{C}$ values of DIC in brines from the NPT reported in Martini et al. (1998) were between +19 and $+32 \%$. Because there is a approximately $2 \%$ fractionation during precipitation (at $10^{\circ} \mathrm{C}$, Deines et al. 1974), the modern calcite scale is in isotopic equilibrium with the produced fluids. Fracture cements with high $\delta^{13} \mathrm{C}$ values occur primarily in samples from well cores, but several cements collected from the Paxton Quarry have values in this 
range. Calcite fracture fill in the second population with very low $\delta^{13} \mathrm{C}$ values occurs predominantly in surface samples, but also in several well cores (Fig. 6B,C). All fracture-fill calcites at the Norwood outcrop are in the second, lower $\delta^{13} \mathrm{C}$ group.

In spite of the broad range in $\delta^{13} \mathrm{C}$ values reported for all fracture fills, on an individual fracture scale the isotopic compositions were nearly homogeneous, with the exception of coarse calcite veins in the Norwood outcrop. Multiple analyses from the same calcite fill in an individual fracture yielded nearly identical results in most fracture fills (Appendix). In contrast, samples from the Norwood outcrop, which contained some of the lowest $\delta^{13} \mathrm{C}$ values, exhibited a marked heterogeneity within individual fracture fills, suggesting multiple episodes of cementation.

Several core samples of fractured Antrim Shale from the western, eastern and southern margin of the Michigan Basin were included in this study (Fig. 1, Appendix). On the western and eastern edge of the basin, calcite cements in fractures have high $\delta^{13} \mathrm{C}$ values, comparable to the first group in the NPT. There is active gas exploration and production in the area southwest of the NPT. However, exploration wells on the eastern side of the Michigan Basin have very low gas production rates. The high $\delta^{13} \mathrm{C}$ values in calcite cements from a core on the eastern margin of the Michigan Basin may indicate a former microbial gas deposit that has since been degraded or eroded. On the southern edge of the Basin, the Antrim Shale is well fractured and has organic carbon contents as high as black shales in the NPT, but cementation within fractures was extremely sparse and there were no cements with high $\delta^{13} \mathrm{C}$ values. These fracture-fill cements have moderately low carbon isotope values $(-11$ to -18 $\delta^{13} \mathrm{C} \%$; Appendix).

\section{Oxygen isotopic composition of fracture-fill cements}

In contrast to the broad range of $\delta^{13} \mathrm{C}$ values in fracture-fill cements, there is a narrow range in $\delta^{18} \mathrm{O}$ values. There is a predictable geographical distribution of $\delta^{18} \mathrm{O}$ values in brines from the Antrim Shale (Walter et al. 1996) that is also observed in the $\delta^{18} \mathrm{O}$ composition of fracture-fill calcite (Fig. 7a). In shallow, northern parts of the reservoir, the $\delta^{18} \mathrm{O}$ of calcite cements is lowest, whereas farther south, deeper in the Antrim reservoir, fracture-fill calcite has higher $\delta^{18} \mathrm{O}$ values. The $\delta^{18} \mathrm{O}$ values of formation brines from presently producing gas wells increase with depth in the reservoir due to mixing with freshwater (Fig. 7A). This increase (from -12 to $-4.0 \delta^{18} \mathrm{O} \%$ SMOW) occurs within a geographically narrow area $(\sim 20 \mathrm{~km}, 12$ miles; Martini et al. 1998). Calcite cements from Antrim fractures within the western, eastern, and southern margins of the Michigan Basin have $\delta^{18} \mathrm{O}$ values comparable to fracture cements in the NPT, although present gas production in most of these areas is quite low compared to that in the NPT (Fig. 7B, Appendix).
In an effort to evaluate a possible connection between calcite cements in fractures and present-day formation fluids, the $\delta^{18} \mathrm{O}$ (SMOW) values of cements were compared to those in brines from nearby producing gas wells (Fig. 8; Appendix) using data presented in Walter et al. (1997) and Martini et al. (1998). When these calcite-water data are compared to experimentally determined fractionation curves for calcite and water between $0{ }^{\circ} \mathrm{C}$ and $25^{\circ} \mathrm{C}$ (Fig. 8; O'Neil et al. 1969), it is apparent that most fracture-fill calcite from the shallowest part of the reservoir is not in isotopic equilibrium with present day formation fluids. These calcite cements all have high $\delta^{13} \mathrm{C}$ values and may have formed at temperatures lower than in the present day reservoir (about $15^{\circ} \mathrm{C}$ ) or precipitated from waters with lower $\delta^{18} \mathrm{O}$ values than are present in the modern reservoir. Calcite from fractures in deeper sections of the Antrim Shale, also with high $\delta^{13} \mathrm{C}$ values, have $\delta^{18} \mathrm{O}$ values that could be derived from present day formation waters. However, it is more likely that the cements from the deeper sections of the Antrim Shale formed at some time in the past from waters with comparable isotope values to those presently in the reservoir.

The modern calcite scale samples, plotted in Fig. 8, reflect formation at higher temperatures than were measured in formation fluids, or precipitation so rapid during degassing within well tubing that the oxygen values are not in equilibrium with reservoir conditions. The higher temperatures implied by the $\delta^{18} \mathrm{O}$ values are related to summer surface temperatures, not reservoir temperatures. Fluid temperatures in the range of $12-17^{\circ} \mathrm{C}$ reported for many wells in the NPT (Martini et al. 1998) are probably not accurate formation temperatures because they were measured at the well head and not at depth in the reservoir. Given the shallow depth in most of the NPT of the Antrim Shale, maximum fluid temperatures should not be greater than $25^{\circ} \mathrm{C}$ (Speece et al. 1985; Cercone \& Pollack 1991) and are probably actually cooler than measured at the surface today.

Whereas local methanogenic processes may control the $\delta^{13} \mathrm{C}$ values in brines within the reservoir, the $\delta^{18} \mathrm{O}$ values are a reflection of mixing between dilute surface recharge water and formation brines at some time in the past. Based on the geographical distribution of $\delta^{18} \mathrm{O}$ in present-day formation water and in calcite cements, it is likely that this reservoir has hosted fluids with similar compositional gradients for a long time. Martini et al. (1998) reported ${ }^{14} \mathrm{C}$ dates of DIC from Antrim Shale brines in the NPT that range from 6 to $27 \mathrm{ka}$ BP. They have interpreted them as residual glacial melt water, which is consistent with their low $\delta^{18} \mathrm{O}$ values (Desaulniers et al. 1981 and references therein). Calcite samples with the lowest oxygen isotopic values are from locations that are within the northern edge of the producing trend where the reservoir is closest to the surface (Figs 7 and 8 ). It is unlikely that these fractures were filled by calcite at temperatures below $0{ }^{\circ} \mathrm{C}$, but it is certainly plausible that lower values in 


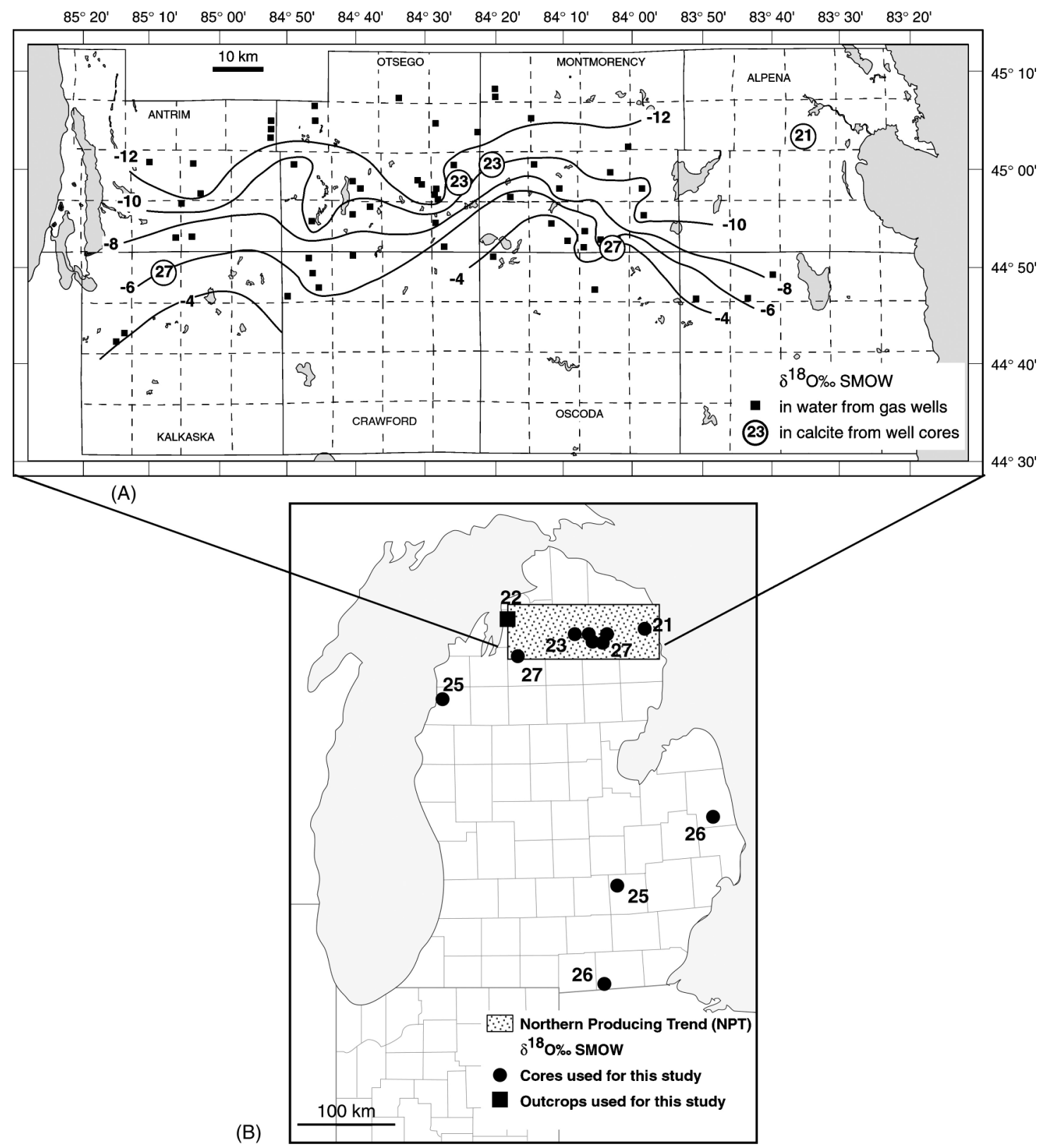

Fig. 7. (A) Detailed map of the Northern Producing Trend of the Antrim Shale showing the $\delta^{18} \mathrm{O}(\mathrm{SMOW}$ ) of formation brines as contours (ranging from -4 to $-12 \%$ ). The stable isotope compositions of calcite cement in core fractures are given as values in circles. (B) Larger state-wide map of $\delta^{18} \mathrm{O}$ (SMOW) values of calcite from Antrim Shale fractures shown as whole numbers. Most samples are from wells (dots) and outcrop sample location is marked by a solid square.

the cements reflect precipitation from fluids with lower $\delta^{18} \mathrm{O}$ values, such as those expected from glacial melt water.

\section{${ }^{14} \mathrm{C}$ and ${ }^{230}$ Th dating of fracture-fill cements}

Radiocarbon analyses of calcite cement from four well cores and one sample from the Norwood outcrop are listed in Table 4. The amount of ${ }^{14} \mathrm{C}$ in the well core cements was below the AMS detection limits of $0.0022-0.00152 \mathrm{Fm}$ (fraction modern), thus these cements formed earlier than 33-49.1 ka вр. The calcite cement sample from the Norwood outcrop had ${ }^{14} \mathrm{C}$ contents of $0.61 \pm 0.2 \mathrm{Fm}$, which yields an uncorrected ${ }^{14} \mathrm{C}$ age of $40.9 \mathrm{ka}$ BP This sample had a $\delta^{13} \mathrm{C}$ of $-17.2 \%$.

Three calcite cement samples from the Norwood outcrop sample were analysed for $\mathrm{U}$ and $\mathrm{Th}$ isotopic compositions to provide another age estimate. The ${ }^{230} \mathrm{Th}$ ages from the Norwood outcrop cements were between 273 and $390 \mathrm{ka}$. 
Table 4 Age determinations of fracture-fill calcite.

\begin{tabular}{|c|c|c|c|c|c|c|}
\hline Sample ID & $\delta^{18} \mathrm{O}(\% \mathrm{PDB})$ & $\delta^{13} \mathrm{C}(\% \mathrm{PDB})$ & ${ }^{14} \mathrm{C}(\mathrm{Fm}) \pm 1 \sigma$ & ${ }^{14} \mathrm{C}$ age (ka BP) & $\delta^{13} \mathrm{C}(\% \mathrm{PDB})^{*}$ & ${ }^{230} \mathrm{Th}$ age $(\mathrm{ka}) \pm 2 \sigma \dagger$ \\
\hline \multicolumn{7}{|c|}{ Outcrop samples } \\
\hline NOR94-2.1 & -7.2 & -21.6 & $0.61( \pm 0.2) \ddagger$ & $41(+2.5 /-1.9) \ddagger$ & -17.2 & $390(+62 /-41)$ \\
\hline NOR94-2.2 & -6.7 & -12.4 & & & & $338(+63 /-41)$ \\
\hline N95-1B.1 & -4.9 & -31.5 & & & & $273(+33 /-23)$ \\
\hline \multicolumn{7}{|l|}{ Well cores } \\
\hline WLL 1588.1 & -7.5 & 17.3 & $F<0.0022$ & $>49$ & 17.6 & \\
\hline SSK 1639 & -3.2 & 25.6 & $F<0.0022$ & $>49$ & 24.1 & \\
\hline TT 1437-1 A & -7.0 & -24.0 & $F<0.0152$ & $>33$ & -29.4 & \\
\hline SC 1179.4 & -3.6 & 24.3 & $F<0.0050$ & $>42$ & 12.7 & \\
\hline
\end{tabular}

*Values from samples analysed for radiocarbon. †Assumes $\left({ }^{230} \mathrm{Th} /{ }^{232} \mathrm{Th}\right)_{\mathrm{i}}=50 \pm 50 \mathrm{ppm}$. Uranium and thorium concentrations and isotopic compositions are available from the Correspondence. $\ddagger$ Analyses from calcite vein NOR94.2, but not same splits as $\delta^{18} \mathrm{O}$ and $\delta^{13} \mathrm{C}$.

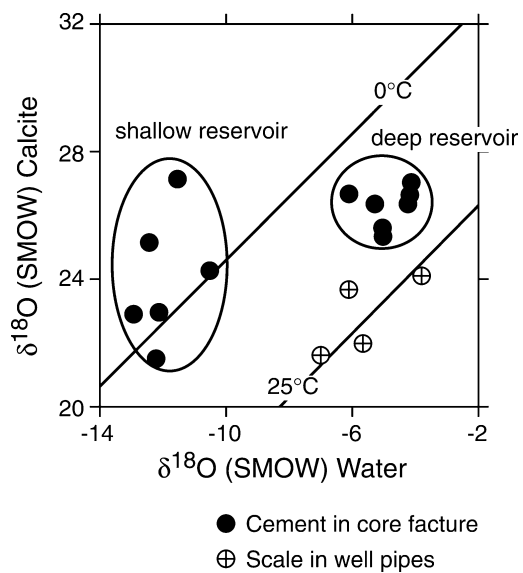

Fig. 8. $\delta^{18} \mathrm{O}$ (SMOW) values of water samples from producing gas wells paired with fracture-fill calcite samples from nearby well cores (dots). Also shown are $\delta^{18} \mathrm{O}(\mathrm{SMOW})$ values of water samples paired with calcite scale samples that precipitated as scale in gas well pipes (circles with crosses). Lines marked with 0 and $25^{\circ} \mathrm{C}$ indicate equilibrium relations between calcite and water, from O'Neil et al. (1969).

\section{DISCUSSION}

The Antrim Shale is an economic natural gas reservoir for a number of reasons, but two factors can be considered within the framework of this study. The first is related to the glacial history of the Great Lakes area. The second factor is the relatively immature condition of the abundant organic matter available within the reservoir itself (Rullkötter et al. 1992). On the margins of the Michigan Basin, the Devonian section was never deeply buried, precluding thermal maturation of the organic rich black shales of the Antrim Shale. The calcite cement lining fractures within the Antrim Shale provides evidence of water sources through its oxygen isotope content, carbon sources through its unusual $\delta^{13} \mathrm{C}$ values, and a temporal framework during which these biogeochemical reactions proceeded.

\section{The role of continental glaciation}

Erosional and depositional processes associated with continental glaciation are critical in the development of surface geology and hydrology in the Great Lakes region (Farrand 1982; Farrand \& Drexler 1985; Farrand \& Eschman 1974; Hoagland 1996). Of special note is the glacial history of northern Michigan, where repeated glacial advances and retreats during the Pleistocene eroded the margins of the basin, alternately exposing Palaeozoic rocks to surficial weathering and then covering subcrops with thick deposits of sand and gravel derived from erosion of the Canadian Shield. The final glacial retreat occurred between 12 and $10 \mathrm{ka} \mathrm{BP}$, leaving behind large moraines composed of gravel, sand, and fine sediment. In the northern part of the Southern Peninsula of Michigan the significant relief of glacial moraines (up to $500 \mathrm{~m}$ ) has provided a thick reservoir for groundwater. Furthermore, rapid glacial rebound of northern Michigan following unloading of the Laurentide ice sheet may have served to open pre-existing fracture networks (Clark 1982), enhancing the infiltration of glacial melt waters. Morainal topography developed as the ice sheet waned and supplied enough hydraulic head to drive surficial recharge into underlying Palaeozoic units that subcrop around the northern margin of the basin.

The northern gas producing trend of the highly fractured Antrim Shale is located immediately basinward of Devonian age subcrops, adjacent to the highest glacial moraines in Michigan. As the Laurentide ice sheet receded, large volumes of meltwater with stable isotopic values distinct from modern meteoric water filled lakes of Late Pleistocene age over much of northern Michigan (Desaulniers et al. 1981; Farrand 1988). In a study closely related to this one, the importance of meteoric recharge in developing microbial methanogenesis within the Antrim Shale has been suggested by evidence from isotopic relations among methane, water and $\mathrm{CO}_{2}$ presently being produced from the NPT and from other Michigan Basin margins (Martini et al. 1996, 1998; Walter 
et al. 1997). Recharge of glacial melt water into a number of other mid-continent basins has been suggested by hydrological and isotopic studies (Coleman et al. 1988; Siegel 1991; Stueber \& Walter 1994; McIntosh et al. 2002).

The timing of fresh water recharge with associated methane production is constrained by the ages of fracture-fill calcite, which record $\delta^{13} \mathrm{C}$ values indicating both methane generating and methane oxidizing processes. The ${ }^{230} \mathrm{Th}$ ages of the fracture fill from the Norwood outcrop range between 273 and $390 \mathrm{ka}$ (Table 4). These results appear to be in conflict with the ${ }^{14} \mathrm{C}$ age of $41 \mathrm{ka}$ вp (Table 4 ). However, there are several ways to account for this discrepancy. Fracture-fill calcite was taken at the present lake water level at the Norwood outcrop. Over the past $10 \mathrm{ka}$ it is likely there have been recurrent fluctuations in lake level and mean annual temperatures, both of which can cause changes in calcite solubility. Modern Lake Michigan is saturated with respect to calcite, so some amount of modern ${ }^{14} \mathrm{C}$ may have been incorporated into these cements during intermittent dissolution and precipitation events within the calcite lined fractures. There is evidence of multiple cementation events at this location, based on carbon isotope results and petrographic observations, described earlier (Figs 4B,C). The addition of any modern ${ }^{14} \mathrm{C}$ would yield an anomalously young age relative to the primary calcite precipitation phase. Alternatively, U loss would cause the ${ }^{230} \mathrm{Th}$ ages to be too old. Uranium is a soluble, mobile element, and U loss could have occurred as lake levels fluctuated, causing variable weathering and precipitation cycles. Calcite cement from fractures in well core samples have ${ }^{14} \mathrm{C}$ concentrations below detection limits and therefore have ages greater than 33-49 ka BP; further U-Th measurements should constrain the formation time of these cements. Despite the uncertainties of calcite cement ages, the measured $\delta{ }^{234} U$ values of cements (130-152) indicate that the $U$ system is not in secular equilibrium, therefore the cements must have formation ages less than $\sim 750 \mathrm{ka}$. The $\mathrm{U}-\mathrm{Th}$ isotopic compositions, in conjunction with the ${ }^{14} \mathrm{C}$ results place the formation of the Norwood calcite samples within the Pleistocene Epoch (1.6 ma to $10 \mathrm{ka})$, with the ${ }^{230}$ Th ages taken to be a maximum and the ${ }^{14} \mathrm{C}$ ages a minimum age (e.g. Ivanovitch \& Harmon 1982; Edwards et al. 1987).

\section{Microbial methanogenesis}

Thermal immaturity of organic matter in the highly organic Antrim Shale provided an environment favorable to microbial methanogenesis. Due to the recharge of surface water via glacial melting, the salinity of basinal brines was diluted and made hospitable for methanogens to flourish in an irregularly shaped mixing interface within the reservoir (Martini et al. 1998). The well-developed fracture network enhanced fluid flow into the black shale, carrying in surface bacterial communities necessary to initiate a complex sequence of microbial reactions leading to methane generation (Martini et al. 1996, 1998).

Given the radioactive age determinations, it is likely that calcite cements in fractures are older than the formation waters presently being produced from the Antrim Shale, and were formed sometime during the Pleistocene. Furthermore, the range of isotopic values within these fracture cements and their geographical distribution strongly suggest that those cements with high $\delta^{13} \mathrm{C}$ values $\left(>8 \% \delta^{13} \mathrm{C}\right.$ ) formed as a by-product during active methanogenesis within the reservoir (Irwin et al. 1977; Siegel et al. 1987). During biogenically mediated methanogenesis, ${ }^{12} \mathrm{C}$ is preferentially concentrated in methane while ${ }^{13} \mathrm{C}$ is enriched in the surrounding water as DIC. Brines from the Antrim Shale are Ca-rich, which allows calcite precipitation when DIC concentration is high (Martini et al. 1998). Calcite cements precipitating from reservoir fluids during this process should have unusually positive $\delta^{13} \mathrm{C}$ values, like those found in these fracture cements. Only microbial processes, via fermentation or $\mathrm{CO}_{2}$ reduction pathways, are capable of producing the extremely high $\delta^{13} \mathrm{C}$ values measured in these cements. All other accessible sources of carbon in rock within this system have $\delta^{13} \mathrm{C}$ values that are much lower. Devonian carbonate units within and adjacent to black shales of the Antrim have a $\delta^{13} \mathrm{C}$ of about $0 \%$; organic carbon in the section has a $\delta^{13} \mathrm{C}$ of $-29 \%$, and early diagenetic calcite and dolomite cements in concretions have negative carbon values $(-5$ to $-12 \%$ ). However, present-day formation brines have high DIC contents with correspondingly high $\delta^{13} \mathrm{C}$ values $(+30 \%)$, as do coproduced $\mathrm{CO}_{2}$ gas $\left(\delta^{13} \mathrm{C}=+19\right.$ to +22\% ; Fig. 6). As described in Martini et al. (1996, 1998), the deuterium isotope values of coproduced methane and formation water indicate methanogenesis via a $\mathrm{CO}_{2}$ reduction pathway. Taken together, the isotopic relationships between carbon and hydrogen within water, $\mathrm{CO}_{2}$ and $\mathrm{CH}_{4}$ form compelling evidence of active microbial methanogenesis via $\mathrm{CO}_{2}$ reduction in the reservoir (Martini et al. 1996).

The highly negative $\delta^{13} \mathrm{C}$ values $(-15$ to $-42 \%$ PDB $)$ contained in the second fracture cement group suggest that these record oxidation of methane or other local organic carbon sources. Both abiotic and biogenically mediated methanotrophic activity could contribute a source of low $\delta^{13} \mathrm{C}$ values to DIC within formation water (Raiswell 1988). Several lines of evidence point to bacterial oxidation within the shallowest parts of the Antrim Shale reservoir (Martini et al. 1998). The isotopic relationships and gas chemistry of methane and ethane reported in Martini et al. (1998) imply that ethane has been preferentially removed, producing a higher $\mathrm{C}_{1} /\left(\mathrm{C}_{2}+\mathrm{C}_{3}\right)$ in the residual methane resource around the northern margin of the Antrim Shale gas producing zone. The $\delta^{13} \mathrm{C}$ values of organic carbon and methane from the Antrim Shale are $-29 \%$ and $-50 \%$ (PDB), respectively. Fracture-fill cement formed from $\mathrm{CO}_{2}$ released via oxidation mixing with calcium-rich formation waters would 
yield calcite with low $\delta^{13} \mathrm{C}$ values, like those in the second group of fracture-lining calcite. The lowest $\delta^{13} \mathrm{C}$ values $\left(-42 \% \delta^{13} \mathrm{C}\right)$ occur in an outcrop exposure of the Norwood Member on the northwest coast of Antrim and Charlevoix Counties, near Norwood, Michigan (Fig. 1, Appendix). These values are much lower than values of DIC in Lake Michigan water $\left(-7.0 \% \delta^{13} \mathrm{C}\right)$, or of carbonate minerals within concretions (Fig. 6).

Microbial sulphate reduction can also lead to precipitation of calcite by increasing the saturation state of carbonate minerals through addition of DIC (e.g. Irwin et al. 1977; Morse \& MacKenzie 1990). Pyrite and other iron sulphide minerals are abundant throughout the Antrim Shale section. However, sulphate reducing bacteria are presently not an important factor in the Antrim reservoir because the concentration of dissolved $\mathrm{SO}_{4}$ is very low $(<1 \mathrm{~mm})$ in nearly all Antrim formation waters from the NPT (Walter et al. 1996). Periodic recharge of fresh water at the basin margin could initiate minor sulphate reduction that would yield associated calcite with a $\delta^{13} \mathrm{C}$ of approximately -10 to $-15 \%$ (Irwin et al. 1977) and there are many samples that are within that range (Fig. 6A,B; Appendix). Alternatively, carbonate rock buffering during organic matter oxidation would yield similar intermediate values (Fig. 6A). However, the only way to explain $\delta^{13} \mathrm{C}$ values lower than $-30 \%$ (PDB) is through oxidation of methane, providing an unequivocal record of microbial degradation of former hydrocarbons within the Antrim reservoir. Figure 9 provides a summary of the range of isotopic values of carbonate in the Antrim Shale and relates them to various pathways of organic matter oxidation.

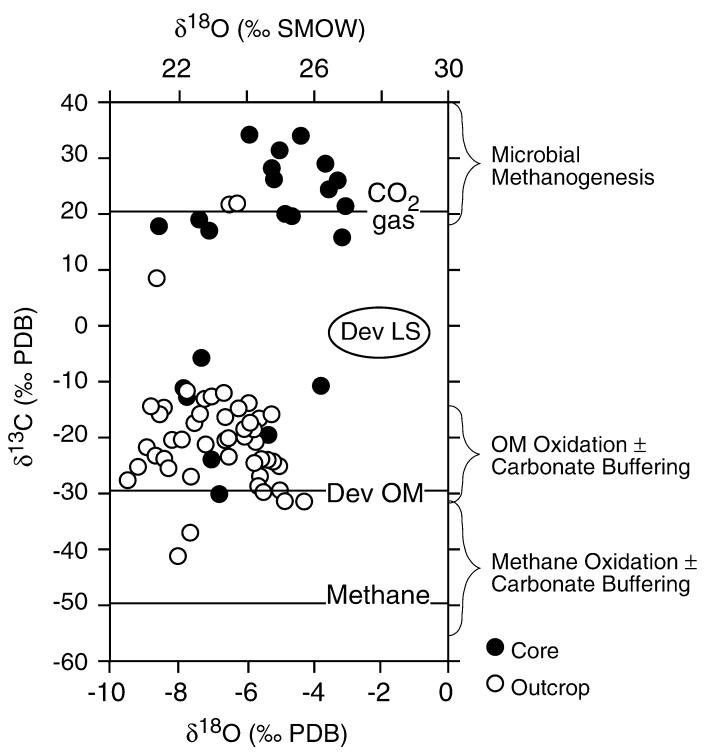

Fig. 9. Stable isotopes ( $\delta^{18} \mathrm{O} \%$ PDB and SMOW, $\delta^{13} \mathrm{C} \%$ PDB) of calcite in core fractures (dots) and outcrop fractures (circles) with fields indicating the dominant source (s) of carbon and processes operating within the reservoir to drive calcite precipitation.
Calcite fracture-fill cement is not common within shallow up-dip areas of the Antrim Shale, either in well cores or exposed in the Paxton Quarry. We infer that fracture cement preservation at the Norwood locality on the northwest edge of the Antrim Shale subcrop was made possible by contact with Lake Michigan water, which is saturated with respect to calcite. Cements are poorly developed within fractures in core samples in all locations examined. The biogeochemical processes that give rise to economic levels of methane may not be favorable for significant carbonate precipitation. The inorganic precipitation of calcite would compete for dissolved carbon with a dynamic microbial community that metabolizes $\mathrm{CO}_{2}$ as part of the methanogenic process (Martini et al. 1996, 1998).

Evidence is retained by unusual calcite fracture fill of a past dynamic microbial community that produced natural gas in a shallow, unconventional reservoir around the margins of the Michigan Basin. There are other, large intracratonic basins with Pleistocene glacial histories and organic black shale sections like that of the Michigan Basin. The conditions that led to the development of an economic gas deposit in the Antrim Shale are not unique and present the possibility of finding shallow, inexpensive natural gas reserves in other North American basins. Gas exploration around the margins of the Michigan Basin, and also within the New Albany Shale of the Illinois Basin, presently continues and studies there suggest that microbial methanogenesis plays an important role in moderating brine chemistry (McIntosh et al. 2002).

\section{CONCLUSIONS}

(1) Calcite with very high $\delta^{13} \mathrm{C}$ values filled fractures in the Antrim Shale and records bacterial methanogenic processes.

(2) Calcite with very low $\delta^{13} \mathrm{C}$ values that also fill fractures in the Antrim Shale formed during bacterial or abiotic methane oxidation.

(3) Methane producing and oxidizing processes were initiated by the recharge of surface waters into the black shale around the shallow margins of the Michigan Basin.

(4) Isotopic evidence supports the interpretation that the cause of this recharge was Pleistocene glacial loading, erosion, deposition and ablation that provided a unique and abundant source of water and the physical drive to infiltrate freshly eroded subcrops of the Antrim Shale.

(5) Identification of unusually high and low $\delta^{13} \mathrm{C}$ values in calcite can be used as evidence of microbial methane generation and oxidation, respectively, and may be helpful in recognizing gas deposits in other sedimentary basins.

\section{ACKNOWLEDGEMENTS}

Support for this project was provided in part by the Gas Research Institute (contract \#5093-220-2704) and the Petroleum Research Fund, administered by the American 
Chemical Society (PRF Grant \#27443 to LMW/JMB; PRF Grant \#35927-LMW and PRF Grant \#36133-GB2-AMM). Additional support was provided by Shell Western Exploration and Production Co., Shell Exploration and Production Technology Co., Chevron Oil Co., and Amoco Exploration Company. Analytical support at the University of Michigan was provided by John Hansen and Lora Wingate. Dr R. Lawrence Edwards, University of Minnesota, generously provided measurements of $\mathrm{U}$ and $\mathrm{Th}$ on several samples. Dr Alden B. Carpenter and Chevron Laboratories kindly provided organic carbon and silica analyses of the Antrim Shale. Dr Carola H. Stearns provided field expertise and extensive advice on fracture interpretations. The authors thank R. C. Burruss, I. Hutcheon and J. C. McIntosh for insightful reviews of this manuscript.

\section{REFERENCES}

Apotria TG, Kaiser CJ, Cain BA (1994) Fracturing and stress history of the Devonian Antrim Shale, Michigan Basin. In: Rock Mechanics (eds Nelson, PP, Lauback, SE), pp. 809-16. Balkema, Rotterdam.

Caramanica FP (1994) Impact of reservoir properties and fractures on gas production, Antrim Shale, Michigan Basin. Gas Research Institute Topical Report, Contract no. 5086-213-1390.

Cercone KR, Pollack HN (1991) Thermal maturity of the Michigan Basin. In: Early Sedimentary Evolution of the Michigan Basin (eds Catacosinos, PP, Daniels, PA), 256. pp. 1-11. Geological Society of America, Special Paper, Boulder, Colorado.

Clark JA (1982) Glacial loading: a cause of natural fracturing and a control of the present stress state in regions of high Devonian shale gas production. Society of Petroleum Engineers/U.S. Department of Energy \#10798. Sol. Pet. Eng., Pittsburgh, PA.

Coleman DD, Liu C-L, Hackley KC, Pelphrey SR (1995) Isotopic identification of landfill methane. Environmental Geosciences, 2, 95-103.

Coleman DD, Liu CL, Riley KM (1988) Microbial methane in the shallow Paleozoic sediments and glacial deposits of Illinois, U.S.A. Chemical Geology, 71, 23-40.

Craddock JP, Jackson M, Van der Pluijm BA, Versical RT (1993) Regional shortening fabrics in eastern North America - far field stress transmission from the Appalachian-Ouachita orogenic belt tectonics. Tectonics, 12, 257-64.

Craddock JP, van der Pluijm BA (1989) Late Paleozoic deformation of the cratonic carbonate cover of eastern North America. Geology, $17,416-9$.

Decker D, Coates JMP, Wicks D (1992) Stratigraphy, gas occurrence, formation evaluation and fracture characterization of the Antrim Shale, Michigan Basin. Gas Research Institute Topical Report, Contract no. 5091-213-2305.

Deines P, Langmuir D, Harmon RS (1974) Stable carbon isotope ratios and existence of a gas-phase in evolution of carbonate ground waters. Geochimica et Cosmochimica Acta, 38, 1147-64.

Dellapenna TM (1991) Sedimentological, structural, and organic geochemical controls on natural gas occurrence in the Antrim Formation in Otsego County, Michigan. Unpublished Masters Thesis. Western Michigan University, Kalamazoo, MI.

Dellapenna TM, Harrison WB (1993) Mineralogic, petrophysical and organic geochemical properties, Antrim Shale, Michigan Basin. In: Antrim Shale Workshop. Gas Research Institute Report, GRI-9310485, 34. Gas Research Institute, Chicago, IL.
Desaulniers DE, Cherry JA, Fritz P (1981) Origin, age and movement of pore water in argillaceous Quaternary deposits at 4 sites in Southwestern Ontario. Journal of Hydrology, 50, 231-57.

Dettman DL, Lohmann KC (1995) Microsampling carbonates for stable isotope and minor element analysis; physical separation on a 20 micrometer scale. Journal of Sedimentary Research, $\mathbf{6 5}$, $566-9$.

Edwards RL, Chen JH, Wasserburg GJ (1987) U-238 U-234-Th230-Th-232 systematics and the precise measurement of time over the past 500000 years. Earth and Planetary Science Letters, 81, 175-92.

Engelder T (1993) Stress Regimes in the Lithosphere. Princeton University Press, Princeton, NY.

Evamy BD (1963) The application of a chemical staining technique to a study of dedolomitization. Sedimentology, 2, 164-70.

Farrand WR (1982) Quaternary Geology of Southern Michigan, 1: 500,000. Michigan Department of Natural Resources, Geological Survey Division, Lansing.

Farrand WR (1988) The Glacial Lakes Around Michigan. Michigan Department of Natural Resources, Geological Survey Division, Bulletin, 4. pp. 1-17. Michigan Department of Natural Resources, Geological Survey Division, Lansing, MI.

Farrand WR, Drexler C (1985) Late Wisconsinan and Holocene history of the Lake Superior basin. Geological Association of Canada Special Paper, 30, 17-32.

Farrand WR, Eschman DF (1974) Glaciation of the Southern Peninsula in Michigan: a review. Michigan Academician, 7, 3156.

Fisher JH, Barratt MW, Droste JB, Shaver RH (1988) Michigan Basin. In: Sedimentary Cover-North America Craton, U.S. (ed. Sloss, L L), D-2, pp. 361-81. Geological Society of America, The Geology of North America. Geological Society of America, Boulder, CO.

Galimov EM (1980) $C^{13} / C^{12}$ in kerogen. In: Kerogen (ed. Durand, B), pp. 271-300. Editions Technip, Paris, France.

Galimov EM, Migdisov AA, Ronov AB (1975) Variation in the isotopic composition of carbonate and organic carbon in sedimentary rocks during Earth's history. Geochemica International, 12, 1-19.

Gross MR, Engelder T (1991) A case for neotectonic joints along the Niagara Escarpment. Tectonics, 10, 631-41.

Gutschick RC, Sandberg CA (1991) Upper Devonian biostratigraphy of Michigan Basin. In: Early Sedimentary Evolution of the Michigan Basin (eds Catacosinos, PA, Daniels, PA), 256, pp. 155-79. Geological Society of America, Special Paper, Geological Society of America, Boulder, CO.

Hathon C, Sibley D, Cambray FW (1980) The origin of quartz in Antrim Shale. U.S. Department of Energy Report FE-2346-61, 32.

Hoagland JR (1996) Recharge to discharge groundwater travel times in the michigan basin and the effect of glacial ice loading. PhD Dissertation. Michigan State University, East Lansing, MI.

Holst TB, Foote GR (1981) Joint orientation in Devonian rocks in the northern portion of the Lower Peninsula of Michigan. Geological Society of America Bulletin Part I, 92, 85-93.

Irwin H, Curtis CD, Coleman ML (1977) Isotopic evidence for source of diagenetic carbonates formed during burial of organicrich sediments. Nature, 269, 209-13.

Ivanovitch M, Harmon RS (1982) Uranium Series Disequilibrium. Applications to Environmental Problems. Oxford University Press, Oxford.

Kesling RV, Johnson AM, Sorensen HO (1976) Devonian Strata of the Afton-Onaway Area, Michigan. University of Michigan Papers on Paleontology, 17, 148. 
Martini AM, Budai JM, Walter LM, Schoell M (1996) Microbial generation of economic accumulations of methane within a shallow organic-rich shale. Nature, 383, 155-8.

Martini AM, Walter LM, Budai JM, Ku TCW, Kaiser CJ, Schoel M (1998) Genetic and temporal relations between formation waters and biogenic methane: Upper Devonian Antrim Shale, Michigan Basin, USA. Geochimica et Cosmochimica Acta, 62, 1699-720.

Martini AM, Walter LM, Ku TCW, Budai JM, Schoell M (in review) Microbial production and modification of gases in sedimentary basins: A geochemical case study from a Devonian shale gas play, Michigan Basin. American Association of Petroleum Geologists Bulletin.

Matthews RD (1993) Review and revisions of the DevonianMississippian stratigraphy in the Michigan Basin. U.S. Geological Survey Bulletin, 1909, D1-D85.

Morse JW, Mackenzie FT (1990) Geochemistry of sedimentary carbonates. Developments in Sedimentology, 48, 707.

O'Neil JR, Clayton RN, Mayeda TK (1969) Oxygen isotope fractionation in divalent metal carbonates. Journal of Chemical Physics, 51, 5547-5558.

Plumb RA, Cox JW (1987) Stress directions in eastern North America determined to $4.5 \mathrm{~km}$ from borehole elongation measurements. Journal of Geophysical Research, 92, 4805-16.

Pollard DD, Aydin A (1988) Progress in understanding jointing over the past century. Geological Society of America Bulletin, 100, 1181-204.

Raiswell R (1988) Chemical model for the origin of minor limestoneshale cycles by anaerobic methane oxidation. Geology, 16, 641-4.

Rullkötter J, Marzi R, Meyers PA (1992) Biological markers in Paleozoic sedimentary rocks and crude oils from the Michigan Basin: reassessment of sources and thermal history of organic matter. In: Early Organic Evolution: Implications for Mineral and Energy Resources (ed. Schidlowski, M), pp. 324-35. SpringerVerlag, New York.

Ruotsala AP (1980) Mineralogy of Antrim Shale, Michigan. U.S. Department of Energy Report FE-2346-79, 85.
Siegel DI (1991) Evidence for dilution of deep, confined ground water by vertical recharge of isotopically heavy Pleistocene water. Geology, 19, 433-6.

Siegel DI, Chamberlain SC, Dossert WP (1987) The isotopic and chemical evolution of mineralization in septarian concretions: Evidence for episodic paleohydrogeologic methanogenesis. Geological Society of America Bulletin, 99, 385-94.

Speece MA, Bowen ED, Folcik JL, Pollack HN (1985) Analysis of temperatures in sedimentary basins; The Michigan Basin. Geophysics, 50, 1318-34.

Stueber AM, Walter LM (1994) Glacial recharge and paleohydrologic flow systems in the Illinois Basin: evidence from chemistry of Ordovician carbonate (Galena) formation waters. Geological Society of America Bulletin, 106, 1430-9.

Versical RT (1991) Basement control on the development of selected Michigan Basin oil fields as constrained by fabric elements in Paleozoic limestones. Masters Thesis. Western Michigan University, Western Michigan.

Walter LM, Budai JM, Abriola LM, Stearns CH, Martini AM, Ku TCW (1996) Hydrogeochemistry of the Antrim Shale, Northern Michigan Basin. Gas Research Institute Annual Report, GRI-95/ $0251,171$.

Walter LM, Budai JM, Martini AM, Ku TCW (1997) Hydrogeochemistry of the Antrim Shale in the Michigan Basin. Gas Research Institute Final Report, GRI-97/0127, 95.

Wardlaw M (1981) Origin and geochemistry of carbonate concretions Antrim Shale (Devonian, Michigan Basin). Unpublished Masters Thesis. Michigan State University, East Lansing, MI.

Zoback ML, Zoback MD (1989) Tectonic stress field of the continental United States. Geological Society of America Memoir, 172, 523-39.

Zuber MD (1995) Advancing the Understanding of Antrim Shale Reservoir Engineering Methods. July 1993 to June 1995. Gas Research Institute, Topical Report, GRI Contract \#5093-2102635, GRI-95/0292.2.

\section{APPENDIX: STABLE ISOTOPE DATA FROM OUTCROP AND CORE SAMPLES. ALL DATA COLLEC- TED IN THE STABLE ISOTOPE LABORATORY AT THE UNIVERSITY OF MICHIGAN.}

\begin{tabular}{|c|c|c|c|c|c|c|}
\hline LOCATION & $\begin{array}{l}\text { MEMBER } \\
\text { SAMPLED }\end{array}$ & MIN & $\begin{array}{l}\delta^{18} \mathrm{O} \\
(\% \text { PDB) }\end{array}$ & $\begin{array}{l}\delta^{18} \mathrm{O} \\
(\% \text { SMOW) }\end{array}$ & $\begin{array}{l}\delta^{13} \mathrm{C} \\
(\% 0 \mathrm{PDB})\end{array}$ & ${ }^{1}$ COMMENTS \\
\hline
\end{tabular}

ALPENA COUNTY

Paxton Quarry, SEC30 T31N-R7E

$\mathrm{PQ4}$

$\mathrm{PQ} 4$

PQ94-3.1

PQ94-3.2

PQ94-5B.1

PQ94-5B.2

PQ94-5A.1

PQ94-5A.2

PQ94 CONC. 1

PQ94 CONC. 2

PQ94-6.1

PQ94-6.2

PAX 2.1

PAX 2.2
FLOAT

FLOAT

FLOAT

FLOAT

FLOAT

LACHINE

LACHINE

LACHINE

LACHINE

FLOAT

FLOAT

LACHINE

LACHINE

PAXTON

PAXTON

\section{OUTCROPS}

$\begin{array}{lrr}\text { CAL } & -5.9 & 24.3 \\ \text { CAL } & -12.2 & 17.8 \\ \text { CAL } & -11.6 & 18.4 \\ \text { CAL } & -7.0 & 23.1 \\ \text { CAL } & -7.8 & 22.4 \\ \text { CAL } & -7.2 & 23.0 \\ \text { CAL } & -7.1 & 23.1 \\ \text { CAL } & -8.5 & 21.6 \\ \text { CAL } & -8.0 & 22.2 \\ \text { CAL } & -6.1 & 24.1 \\ \text { DOL } & -7.5 & 22.7 \\ \text { CAL } & -7.6 & 22.6 \\ \text { CAL } & -8.4 & 21.8 \\ \text { CAL } & -4.9 & 25.4 \\ \text { CAL } & -5.3 & 24.9\end{array}$

$$
\begin{array}{r}
-11.8 \\
0.8 \\
3.4 \\
-11.0 \\
-10.3 \\
-13.2 \\
-13.1 \\
-24.3 \\
-20.6 \\
-0.9 \\
-15.2 \\
-37.3 \\
-25.9 \\
-1.6 \\
-1.0
\end{array}
$$

Prismatic cement in concretion
$1^{\text {st }}$ side of vein
2 nd side of vein
Vein
Vein
horizontal vein
horizontal
vertical
vertical
cement in concretion, brown, coarse
cement in concretion, pink, course
vertical vein, 1st face
vertical vein, 2nd face
wall rock
wall rock


APPENDIX: Continued

\begin{tabular}{|c|c|c|c|c|c|c|}
\hline LOCATION & $\begin{array}{l}\text { MEMBER } \\
\text { SAMPLED }\end{array}$ & MIN & $\begin{array}{l}\delta^{18} \mathrm{O} \\
(\% 0 \text { PDB) }\end{array}$ & $\begin{array}{l}\delta^{18} \mathrm{O} \\
(\% \text { SMOW) }\end{array}$ & $\begin{array}{l}\delta^{13} \mathrm{C} \\
\left(\%{ }^{\mathrm{PDB}}\right)\end{array}$ & ${ }^{1}$ COMMENTS \\
\hline PAX 5.1 & PAXTON & CAL & -5.2 & 25.0 & -2.3 & wall rock \\
\hline PAX 5.2 & PAXTON & CAL & -5.1 & 25.2 & -2.3 & wall rock \\
\hline PAX 7.1 & PAXTON & $C+D$ & -6.1 & 24.1 & -6.9 & wall rock \\
\hline PAX 10.1 & PAXTON & $C+D$ & -5.0 & 25.3 & -0.8 & wall rock \\
\hline PAX 12.1 & PAXTON & $C+D$ & -7.3 & 22.9 & -4.8 & wall rock \\
\hline $\operatorname{PAX} 7.2$ & PAXTON & DOL & -5.4 & 24.8 & -4.7 & Dol crust/vein? \\
\hline PAX 10.2 & PAXTON & DOL & -4.9 & 25.3 & -0.5 & dol crust/vein? \\
\hline PAX 12.2 & PAXTON & DOL & -5.1 & 25.1 & -2.2 & dol crust/vein \\
\hline PQ94L-1.1 & LACHINE & CAL & -8.6 & 21.6 & -15.7 & bedding plane vein \\
\hline PQ94L-1.2 & LACHINE & CAL & -8.5 & 21.7 & -15.2 & bedding plane vein \\
\hline PQ94L-2.1 & LACHINE & CAL & -9.0 & 21.1 & -22.2 & vertical vein, N64E, brown stain \\
\hline PQ94L-3.1 & LACHINE & CAL & -8.7 & 21.4 & 8.6 & vertical vein, N49E \\
\hline PQ94L-4.1 & LACHINE & CAL & -6.5 & 23.7 & 21.4 & vertical vein, $\mathrm{N} 46 \mathrm{E}$ \\
\hline PQ94L-4.2 & LACHINE & CAL & -6.3 & 23.8 & 21.7 & vertical vein, $\mathrm{N} 46 \mathrm{E}$ \\
\hline PQ94L-5.1 & LACHINE & CAL & -7.7 & 22.4 & -12.1 & vertical vein, N53W \\
\hline PQ94L-5.2 & LACHINE & CAL & -7.8 & 23.3 & -12.1 & vertical vein, N53W \\
\hline PQ94L-6.1 & LACHINE & CAL & -9.3 & 20.8 & -25.5 & vertical vein, N61W \\
\hline PQ94L-62 & LACHINE & CAL & -8.7 & 21.4 & -23.9 & vertical vein, N61W \\
\hline PQVH 1.1 & PAXTON & CAL & -9.7 & 20.4 & -0.3 & hi angle vein \\
\hline PQVH-2.1 & PAXTON & CAL & -9.3 & 20.8 & 7.5 & hi anlge vein \\
\hline P95-1 & LACHINE & CAL & -7.4 & 22.8 & -6.4 & bp vein \\
\hline P95-2 & LACHINE & CAL & -8.8 & 21.3 & -14.9 & vertical N55W vein (315) \\
\hline \multicolumn{7}{|c|}{ Hycrude Core-Paxton Quarry } \\
\hline HC18.1 & UP-ANTR & CAL & -9.5 & 20.6 & -24.1 & low angle frac coating \\
\hline HC18.2 & UP-ANTR & CAL & -10.0 & 20.0 & -27.2 & low angle frac coating \\
\hline HC19.1 & UP-ANTR & DOL & -6.9 & 23.2 & -9.9 & brn dol-1, concretion \\
\hline $\mathrm{HC} 19.2$ & UP-ANTR & DOL & -8.2 & 22.0 & -16.2 & white dol-2, concretion \\
\hline HC19.3 & UP-ANTR & DOL & -7.0 & 23.2 & -12.2 & clear dol-3, concretion \\
\hline HC19.4 & UP-ANTR & DOL & -7.8 & 22.4 & -14.4 & yellow dol-4 \\
\hline HC28.1 & LACHINE & CAL & -8.9 & 21.2 & -16.4 & mad angle frac coating \\
\hline $\mathrm{HC} 28.2$ & LACHINE & CAL & -12.3 & 17.7 & -28.7 & med angle frac coating \\
\hline HC57.9 & LACHINE & & & & -30.0 & organic carbon in black shale \\
\hline HC101.1 & NORWOOD/TRAV & CAL & -9.8 & 20.3 & -3.2 & cal-1, concretion \\
\hline HC101.2 & NORWOOD/TRAV & DOL & -10.6 & 19.5 & -15.6 & pink dol, concretion \\
\hline HC101.3 & NORWOOD/TRAV & CAL & -2.1 & 28.2 & -9.7 & cal-2, brown, concretion \\
\hline HC107.9 & NORWOOD & & & & -28.0 & organic carbon in black shale \\
\hline \multicolumn{7}{|c|}{ ANTRIM COUNTY } \\
\hline \multicolumn{7}{|c|}{ Norwood Outcrop, SEC3-T32N-R9W } \\
\hline NOR94-1 & NORWOOD & CAL & -8.0 & 22.1 & -41.7 & vein, N60E \\
\hline NOR94-2.1 & NORWOOD & CAL & -7.2 & 22.9 & -21.6 & edge of vein, N34W \\
\hline NOR94-2.2 & NORWOOD & CAL & -6.7 & 23.5 & -12.4 & center of vein N34W \\
\hline N95-1A.1 & NORWOOD & CAL & -5.2 & 25.0 & -24.3 & N76E, center of vein, piece 1 \\
\hline N95-1A.2 & NORWOOD & CAL & -5.9 & 24.3 & -17.5 & N76E, near edge of vein, piece 1 \\
\hline N95-1A.3 & NORWOOD & CAL & -5.4 & 24.9 & -24.3 & N76E, wall edge of vein, piece 1 \\
\hline N95-1A.4 & NORWOOD & CAL & -6.6 & 23.6 & -20.7 & N76E, stained, center, piece 2 \\
\hline N95-1A.5 & NORWOOD & CAL & -7.4 & 22.8 & -16.1 & $\mathrm{~N} 76 \mathrm{E}$, stained, edge, piece 2 \\
\hline N95-1A.6 & NORWOOD & CAL & -6.0 & 24.2 & -19.9 & N76E, center, piece 3 \\
\hline N95-1A.7 & NORWOOD & CAL & -4.2 & 26.0 & -31.7 & N76E, edge, piece 3 \\
\hline N95-1B.1 & NORWOOD & CAL & -4.9 & 25.3 & -31.5 & N76E, center of vein, piece 1 \\
\hline N95-1B.2 & NORWOOD & CAL & -5.4 & 24.8 & -24.1 & N76E, edge of vein, pc 1 \\
\hline N95-1B.3 & NORWOOD & CAL & -5.7 & 24.5 & -27.0 & N76E, stained, center, pc 2 \\
\hline N95-1B.4 & NORWOOD & CAL & -6.7 & 23.5 & -16.7 & N76E, stained, edge, pc 2 \\
\hline N95-3A.1 & NORWOOD & CAL & -5.5 & 24.7 & -29.7 & N60W, center coarse vein pc 1 \\
\hline N95-3A.2 & NORWOOD & CAL & -8.2 & 21.9 & -20.9 & N60W, wall edge of vein, pc 1 \\
\hline N95-3A.3 & NORWOOD & CAL & -5.7 & 24.5 & -24.6 & N60W, center coarse vein, $p c 2$ \\
\hline N95-3A.4 & NORWOOD & CAL & -6.5 & 23.6 & -23.5 & N60W, wall edge of vein, pc 2 \\
\hline N95-3B.1 & NORWOOD & CAL & -5.7 & 24.5 & -28.7 & $\mathrm{~N} 10 \mathrm{E}$, thinner than $\mathrm{A}$, vein center, $\mathrm{pc} 1$ \\
\hline N95-3B.2 & NORWOOD & CAL & -5.6 & 24.6 & -16.9 & $\mathrm{~N} 10 \mathrm{E}$, wall edge of vein, $\mathrm{pc} 1$ \\
\hline N95-3B.3 & NORWOOD & CAL & -5.3 & 24.9 & -15.9 & $\mathrm{~N} 10 \mathrm{E}$, center of vein, $\mathrm{pc} 2$, coarse $>\mathrm{pc} 1$ \\
\hline
\end{tabular}


APPENDIX: Continued

\begin{tabular}{lllllll}
\hline LOCATION & $\begin{array}{l}\text { MEMBER } \\
\text { SAMPLED }\end{array}$ & MIN & $\begin{array}{l}\delta^{18} \mathrm{O} \\
(\% \mathrm{PDB})\end{array}$ & $\begin{array}{l}\delta^{18} \mathrm{O} \\
(\% \mathrm{SMOW})\end{array}$ & $\begin{array}{l}\delta^{13} \mathrm{C} \\
(\% \mathrm{PDB})\end{array}$ & \begin{tabular}{l}
${ }^{1} \mathrm{COMMENTS}$ \\
\hline N95-3B.4
\end{tabular} \\
N95-3B.5 & NORWOOD & CAL & -5.8 & 24.4 & -20.8 & N10E, wall edge, vein, pc 2 \\
N95-4A.1 & NORWOOD & CAL & -5.0 & 25.2 & -25.4 & N10E, between center and edge, pc 2 \\
N95-4A.2 & NORWOOD & CAL & -5.9 & 24.2 & -13.9 & N63E, vertical, center, white, pc 1 \\
N95-4A.3 & NORWOOD & CAL & -9.5 & 20.6 & -28.3 & N63E, vertical, wall edge of vein, gray, pc 1 \\
N95-4A.4 & NORWOOD & CAL & -6.2 & 24.0 & -14.9 & N63E, stained, wall edge, needle xls, pc 2 \\
N95-4B.1 & NORWOOD & CAL & -7.6 & 22.6 & -17.2 & N63E, center of vein, pc 2 \\
N95-7.1 & NORWOOD & CAL & -5.0 & 25.2 & -29.7 & N30W, center of vein, pc 1 \\
N95-7.2 & NORWOOD & CAL & -6.1 & 24.1 & -19.3 & N30W, stained, vein center, pc 1 \\
N95-7.3 & NORWOOD & CAL & -7.7 & 22.5 & -27.2 & N30W, stained, wall edge vein, pc 1 \\
N95-7.4 & NORWOOD & CAL & -5.9 & 24.3 & -18.4 & N30W, unstained, vein center, pc 2 \\
& NORWOOD & CAL & -6.5 & 23.6 & -20.3 & N30W, frac wall edge, pc 2
\end{tabular}

\section{CRAWFORD COUNTY}

SWEPI St. S. Branch 1-19, SEC 19-T25N-R1W

$$
\text { 2098.3 LACHINE }
$$

$-20.3$

KALKASKA COUNTY

Shell St. Kalkaska 3-11. SEC 11-T28N-R7W

1604.4

1639

1641

$1621.2 \mathrm{~A}$

1621.2B

LENAWEE COUNTY

Yohe Thomas 1-28, SEC 28-T8S-R2E

LIVINGSTON COUNTY

Mercury Dey A1-15, SEC 15-T3, R3E

MD 1693.5A

MD 1693.5B NORWOOD

MD 1537

MD 1674.7

LACHINE

NORWOOD

MANISTEE COUNTY

Oil Joseph 3-22, SEC 22-T23N-R16N

OJ 1026-1

OJ 1047-1

OJ 1047-1 SPLIT

OJ $1047-2$

OJ 1063-2

OJ 1064.5-1

OJ 1064.5-2

OJ 1064.5-2 SPLIT

OJ $1114-2$

OJ $1078.5-1$

OJ $1078.5-2$

OJ 1078.5-3

OJ 1078.5-4

OJ $1078.5-5$

OJ 1078.5-6

OJ 1078.5-7

MONTMORENCY COUNTY

Shell St. Loud C2-31, SEC 31-T29N-R3E

1579.9A

$1579.9 B$

1584.9A

$1584.9 \mathrm{~B}$

1564.9

1470

1559.5

LACHINE

LACHINE

LACHINE

LACHINE

LACHINE

LACHINE

NORWOOD

PAXTON

PAXTON

PAXTON

PAXTON

PAXTON

PAXTON

PAXTON

TRAVERSE

TRAVERSE

TRAVERSE

TRAVERSE

NORWOOD

LACHINE

NORWOOD

$\begin{array}{lrrr}\text { CAL } & -4.8 & 25.4 & 20.0 \\ \text { CAL } & -4.6 & 25.6 & 19.6 \\ \text { Blk Shale } & & & -30.1 \\ \text { Blk Shale } & & & -30.5\end{array}$

$\begin{array}{lrrr}\text { CAL } & -15.7 & 14.2 & 8.4 \\ \text { CAL } & -5.0 & 25.2 & 31.3 \\ & -5.0 & 25.3 & 30.9 \\ \text { CAL } & -5.9 & 24.3 & 34.0 \\ \text { CAL } & -5.2 & 25.0 & 28.5 \\ \text { CAL } & -5.1 & 25.1 & 25.6 \\ \text { CAL } & -5.1 & 25.1 & 26.2 \\ & -5.2 & 25.0 & 26.1 \\ \text { CAL } & -5.4 & 24.8 & -19.6 \\ \text { CAL } & -5.8 & 24.4 & -9.7 \\ \text { CAL } & -8.0 & 22.2 & -6.1 \\ \text { DOL } & -4.7 & 25.5 & -5.1 \\ \text { CAL } & -0.4 & 30.0 & -5.3 \\ \text { CAL } & -5.6 & 24.6 & -7.2 \\ \text { CAL } & -6.6 & 23.5 & -7.1 \\ \text { DOL } & -8.4 & 21.8 & -4.7\end{array}$

$\begin{array}{lll}\text { CAL } & -7.3 & 22.8\end{array}$

$\begin{array}{lll}\text { DOL } & -7.5 & 22.7\end{array}$

$\begin{array}{lll}\text { CAL } & -7.3 & 22.9\end{array}$

$\begin{array}{lll}\text { DOL } & -7.0 & 23.2\end{array}$

$\begin{array}{lll}\text { CAL } & -7.8 & 23.2\end{array}$

SWEPI St. Loud D3-20, SEC 20-T29N-R3E 963.8 UP ANTR

$\begin{array}{lllrl}\text { CAL } & -3.6 & 26.7 & 24.3 & \text { hi angle vein } \\ \text { CAL } & -3.2 & 27.1 & 25.6 & \text { hi angle vein } \\ \text { CAL } & -3.1 & 27.2 & 21.3 & \text { hi angle vein } \\ \text { CAL } & -4.4 & 25.9 & 20.7 & \text { last cement in concretion, dedolomite } \\ \text { DOL } & -7.8 & 22.3 & -10.4 & \text { hi angle vein in concretion, 1st cement }\end{array}$

20.0

19.6

$-30.5$

hi angle vein

hi angle vein $w / b r$ stuff

organic carbon

organic carbon

cement on low angle fracture

bp vein $w /$ pyrite nuggets

split of same

same, different spot

bp vein

bp vein $w /$ pyrite

same, different spot

split of above

low angle fracture, thin cement

limestone (stained)

1 st cement in concretion (stained)

2nd cement in concretion (stained)

3 rd cement in concretion (stained)

limestone wall rock (unstained)

1st cement in concretion (unstained)

2nd cement in concretion (unstained)

$\begin{aligned}-4.0 & \text { wall rock } \\ -3.2 & \text { wall rock } \\ -4.1 & \text { wall rock } \\ -2.9 & \text { wall rock } \\ -4.5 & \text { conforted veinlet w/pyrite } \\ -29.5 & \text { organic carbon in black shale } \\ -30.2 & \text { organic carbon in black shale } \\ -29.4 & \text { organic carbon in black shale }\end{aligned}$

(C) 2002 Blackwell Science Ltd, Geofluids, 2, 163-183 
APPENDIX: Continued

\begin{tabular}{|c|c|c|c|c|c|c|}
\hline LOCATION & $\begin{array}{l}\text { MEMBER } \\
\text { SAMPLED }\end{array}$ & MIN & $\begin{array}{l}\delta^{18} \mathrm{O} \\
(\% 0 \mathrm{PDB})\end{array}$ & $\begin{array}{l}\delta^{18} \mathrm{O} \\
(\% \text { SMOW) }\end{array}$ & $\begin{array}{l}\delta^{13} \mathrm{C} \\
\left(\%{ }^{\mathrm{PDB}}\right)\end{array}$ & ${ }^{1}$ COMMENTS \\
\hline \multicolumn{7}{|c|}{ Shell Caruso C2-28C SEC 28-T29N-R3E } \\
\hline 1179.4 & LACHINE & CAL & -3.6 & 26.7 & 24.3 & vertical vein $w /$ pyrite \\
\hline $1226.2 \mathrm{~A}$ & NORWOOD & DOL & -3.2 & 27.1 & 25.6 & gash vein (in concretion?) \\
\hline $1226.2 B$ & NORWOOD & CAL & -3.1 & 27.2 & 21.3 & gash vein (in concretion?) \\
\hline $1226.2 \mathrm{C}$ & NORWOOD & CAL & -5.5 & 24.8 & -10.0 & gash vein (in concretion?) \\
\hline \multicolumn{7}{|c|}{ Trend Stevens Mins 2-15, SEC 15-T30N-R3E } \\
\hline $747 \mathrm{~A}$ & NORWOOD & DOL & -11.8 & 18.2 & -13.7 & Concretion, vein center \\
\hline 747B & NORWOOD & CAL & -5.4 & 24.8 & -7.2 & Concretion, vein edge \\
\hline $747 C$ & NORWOOD & CAL & -8.2 & 21.9 & -2.8 & Concretion, vein center \\
\hline 747D & NORWOOD & CAL & -5.0 & 25.2 & -4.9 & Concretion \\
\hline 757.5 & NORWOOD & CAL & -8.1 & 22.0 & -6.8 & concretion? breccia zone w/prite \\
\hline 758 & NORWOOD & CAL & -3.1 & 27.2 & 15.9 & hi angle fracture coating, sparse \\
\hline \multicolumn{7}{|c|}{ Trendwell Thompson 1-8, SEC 8-T30N-R1E } \\
\hline $1437-1 \mathrm{~A}$ & LACHINE & CAL & -7.0 & 23.1 & -24.0 & hi anlge vein, N45E \\
\hline 1437-1B & LACHINE & CAL & -7.1 & 23.1 & -24.6 & hi angle vein w/pyrite, N45E \\
\hline $1437-2$ & LACHINE & CAL & -6.8 & 23.4 & -30.3 & hi anlge vein, N45E \\
\hline $1518.7 \mathrm{~A}$ & SQB/TRAV & CAL & -7.8 & 22.4 & -13.2 & lo anlge vein \\
\hline 1518.7B & SQB/TRAV & CAL & -3.6 & 26.7 & -6.1 & wall rock \\
\hline \multicolumn{7}{|c|}{ Caruso CH-2, SEC 28-T29N-R3E } \\
\hline $\mathrm{CCH} 2-1189-1$ & LACHINE & CAL & -3.4 & 26.8 & 29.1 & hi anlge fracture, N60E \\
\hline $\mathrm{CCH} 2-1189-2$ & LACHINE & CAL & -3.8 & 26.5 & 24.2 & dif site, same fracture, N60E \\
\hline \multicolumn{7}{|l|}{ OTSEGO COUNTY } \\
\hline \multicolumn{7}{|c|}{ Ward Latuscek B1-32, SEC 32-T30N-R1W } \\
\hline $1602.3 \mathrm{~A}$ & LACHINE & DOL & -9.7 & 20.4 & -9.6 & Concretion wall rock \\
\hline $1602.3 B$ & LACHINE & DOL & -9.5 & 20.6 & -11.5 & Concretion wall rock \\
\hline $1602.3 C$ & LACHINE & CAL & -9.6 & 20.4 & -11.9 & Concretion \\
\hline 1602.3D & LACHINE & DOL & -12.1 & 17.9 & -15.1 & Concretion \\
\hline $1717 \mathrm{~A}$ & SQ BAY & DOL & -12.5 & 17.5 & -8.5 & Concretion \\
\hline 1717B & SQ BAY & CAL & -4.2 & 26.0 & -1.7 & Concretion \\
\hline 1716.6 & SQ BAY & CAL & -4.6 & 25.6 & -9.1 & Concretion \\
\hline 1588.1 & LACHINE & CAL & -7.5 & 23.1 & 17.3 & vein \\
\hline $1589 \mathrm{~A}$ & LACHINE & CAL & -8.6 & 21.5 & 17.6 & Thin vertical vein \\
\hline 1589B & LACHINE & CAL & -7.1 & 23.0 & 16.9 & vertical vein, N7OE \\
\hline $1589 \mathrm{C}$ & LACHINE & CAL & -7.4 & 22.7 & 16.7 & vertical vein, N56E \\
\hline 1613.7 & LACHINE & CAL & -7.4 & 22.7 & 18.8 & bedding plane vein, prismatic \\
\hline 1646.7A & PAXTON & CAL & -7.3 & 22.8 & -6.3 & lo angle vein, clear \\
\hline 1646.7B & PAXTON & CAL & -5.2 & 25.0 & -0.8 & wall rock \\
\hline $1705 \mathrm{~A}$ & NOR/SQB & CAL & -10.2 & 19.9 & -10.9 & Concretion \\
\hline 1705B & NOR/SWB & CAL & -3.9 & 26.4 & -11.4 & wall rock \\
\hline \multicolumn{7}{|c|}{ Welch St. Chester \#18, SEC 13, T29N, RZW } \\
\hline $1519 A$ & LACHINE & DOL & -10.0 & 20.1 & -13.6 & Concretion \\
\hline 1519B & LACHINE & DOL & -9.2 & 20.8 & -10.1 & wall rock \\
\hline \multicolumn{7}{|l|}{ SANILAC COUNTY } \\
\hline \multicolumn{7}{|c|}{ DOW ERDA \#103, SEC 8-9N-15E } \\
\hline 1335 & Upper Antrim & CAL & -4.4 & 25.8 & 34.0 & vertical fracture, N24E \\
\hline \multicolumn{7}{|l|}{ SCALE } \\
\hline \multicolumn{7}{|c|}{ scale from a Crawford Cty well } \\
\hline inner edge, oldest scale & & CAL & -8.1 & 22.0 & 29.0 & \\
\hline next & & CAL & -8.1 & 22.0 & 28.9 & \\
\hline next & & CAL & -8.4 & 21.8 & 29.2 & \\
\hline next & & CAL & -8.2 & 22.0 & 29.1 & \\
\hline next & & CAL & -8.4 & 21.7 & 29.3 & \\
\hline next & & CAL & -8.3 & 21.8 & 29.4 & \\
\hline outer edge, youngest scale & & CAL & -8.2 & 21.9 & 29.2 & \\
\hline \multicolumn{7}{|c|}{ scale from a Montmorency Cty well } \\
\hline scale A & & CAL & -6.0 & 24.2 & 25.0 & \\
\hline scale B & & CAL & -6.5 & 23.7 & 21.3 & \\
\hline
\end{tabular}

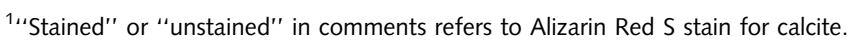

